\title{
Ulva lactuca polysaccharides prevent Wistar rat breast carcinogenesis through the augmentation of apoptosis, enhancement of antioxidant defense system, and suppression of inflammation
}

\author{
This article was published in the following Dove Press journal: \\ Breast Cancer - Targets and Therapy \\ 27 February 2017 \\ Number of times this article has been viewed
}

\author{
Gamal-Eldein F Abd-Ellatef' \\ Osama MAhmed ${ }^{2}$ \\ Eman S Abdel-Reheim² \\ Abdel-Hamid Z \\ Abdel-Hamid'
}

'Pharmaceutical and Drug Industries Research Division, Therapeutic Chemistry Department, National Research Centre, Cairo, Egypt; ${ }^{2}$ Division of Physiology, Department of Zoology, Faculty of Science, BeniSuef University, Beni-Suef, Egypt

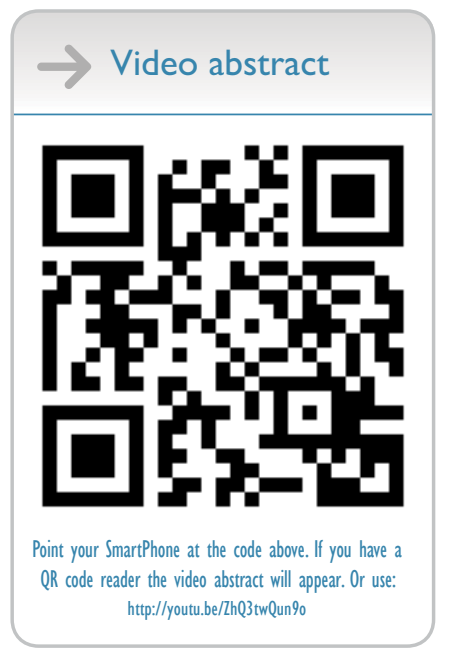

Correspondence: Gamal-Eldein F Abd-Ellatef

Pharmaceutical and Drug Industries Research Division, Therapeutic Chemistry Department, National Research Centre, 33 El-Buhouth Street, Dokki, Giza, Cairo 12622, Egypt Email gamalology@yahoo.com
Background: Recently, several research studies have been focused on the isolation and function of the polysaccharides derived from different algal species, which revealed multiple biological activities such as antioxidant and antitumor activities. This study assesses the possible breast cancer chemopreventive properties of common seaweeds, sea lettuce, Ulva lactuca (ulvan) polysaccharides using in vitro bioassays on human breast cancer cell line (MCF-7) and an in vivo animal model of breast carcinogenesis.

Methods: Cytotoxic effect of ulvan polysaccharides on MCF-7 was tested in vitro. For an in vivo investigation, a single dose of $25 \mathrm{mg} / \mathrm{kg}$ body weight 7,12-dimethylbenz[a]anthracene (DMBA) and ulvan polysaccharides ( $50 \mathrm{mg} / \mathrm{kg}$ body weight every other day) for 10 weeks were administered orally to the Wistar rats.

Results: Deleterious histopathological alterations in breast tissues including papillary cyst adenoma and hyperplasia of ductal epithelial lining with intraluminal necrotic materials and calcifications were observed in the DMBA-administered group. These lesions were prevented in the DMBA-administered group treated with ulvan polysaccharides. The immunohistochemical sections depicted that the treatment of DMBA-administered rats with ulvan polysaccharides markedly increased the lowered pro-apoptotic protein, p53, and decreased the elevated anti-apoptotic marker, bcl2, expression in the breast tissue. The elevated lipid peroxidation and the suppressed antioxidant enzyme activities in DMBA-administered control were significantly prevented by the treatment with ulvan polysaccharides. The elevated levels of inflammatory cytokines tumor necrosis factor- $\alpha$ and nitric oxide were significantly ameliorated in DMBA-administered rats treated with ulvan polysaccharides as compared to DMBA-administered control.

Conclusion: In conclusion, ulvan polysaccharides at the level of initiation and promotion might have potential chemopreventive effects against breast carcinogenesis. These preventive effects may be mediated through the augmentation of apoptosis, suppression of oxidative stress and inflammation, and enhancement of antioxidant defense system.

Keywords: breast carcinogenesis, cancer initiation, cancer promotion, Ulva lactuca polysaccharides, DMBA, oxidative stress, apoptosis

\section{Introduction}

Cancer is one of the most worldwide spread diseases. Breast cancer is the most common malignancy and a leading cause of cancer-related death in women around the world. ${ }^{1}$ Worldwide, it is estimated that $>1$ million women are diagnosed with breast cancer every year, and that $>40 \%$ of these patients die from the disease, representing $14 \%$ of female cancer deaths. ${ }^{2}$ The multistep process including initiation, promotion, 
and progression of carcinogenesis is a complicated process that results from excessive production of oxidative radicals, DNA alterations, and lastly the loss of the normal regulatory pathways between cell proliferation, differentiation, and apoptosis. . $^{3,4}$

Progress made in cancer therapy has not been sufficient to minimize the annual death rates. The currently used conventional anticancer drugs are also toxic to normal cells in addition to being toxic to cancer cells. ${ }^{5}$ Hence, there is a greater need for new effective and safe strategies in cancer control and therapy. Prevention is the most practical strategy to control occurrence and spread of cancer. ${ }^{6}$ Cancer chemoprevention aims to stop or reverse the development and progression of precancerous cells through the use of non-cytotoxic nutrients and/or pharmacologically active agents. It is also important to provide various cancer chemopreventive natural agents with different specific molecular and cellular targets, which act through multiple mechanisms. ${ }^{6}$ Many polysaccharides have been isolated from mushrooms, algae, fungi, yeasts, lichens, and plants, and their biological activities because of their immunomodulatory, antioxidant, and anti-cancer effects have been described ${ }^{7,8}$ Algal polysaccharides have been demonstrated to play an important role as free-radical scavengers and antioxidants for the prevention of oxidative damage in living organisms. ${ }^{4}$

Polycyclic aromatic hydrocarbon (PAH) carcinogen, 7,12-dimethylbenz[a]anthracene (DMBA)-induced mammary gland tumor in rodents has been widely used as an animal model for the development of chemopreventive drugs for breast cancer in humans. ${ }^{9}$ DMBA has been widely evaluated for its carcinogenicity and is often used as a model compound for breast cancer, skin cancer, leukemia, and other cancers in rodent. ${ }^{10}$

The antitumor activity of polysaccharides isolated from Ulva lactuca, a marine alga widely distributed at Egyptian sea shores, has rarely been investigated. Only two available publications revealed that ulvan sulfated polysaccharide has antiproliferative effects on tumoral colon carcinoma cell lines (HCT-29, HCT-116, and Caco-2), hepatocellular carcinoma cell lines (HepG2), and Ehrlich ascites carcinoma (EAC) cells. ${ }^{11,12}$ However, the effects of $U$. lactuca polysaccharides on breast carcinoma are not yet studied. Thus, the present study was designed to validate the effects of ulvan polysaccharides on breast carcinogenesis on the level of initiation and promotion in vivo and on breast carcinoma cell lines (MCF-7) in vitro and to suggest the mechanism of action by investigating the effects on oxidative stress, antioxidant defense system, apoptosis, and inflammation.

\section{Materials and methods \\ Green alga U. lactuca collection and manipulation}

The fresh marine green alga, U. lactuca (Figure 1), was collected from the Mediterranean Sea coast, Alexandrian shores, Egypt, in September 2006. It was identified and authenticated by Prof Dr Ibraheem B M Ibraheem, Professor of Phycology (Algology), Department of Botany, Faculty of Science, Beni-suef University. Epiphytes and sand were removed. The alga was washed with sea water, tap water, and then distilled water several times, air dried in the shade, and stored in plastic bags at room temperature in a dry and dark place before use.

\section{Chemicals}

DMBA was obtained from Sigma-Aldrich (Sigma-Aldrich, VA, USA). Mineral oil was obtained from Sigma-Aldrich (Germany). All other chemicals were of highest purity and analytical grade and were obtained from common commercial suppliers.

\section{Experimental animals}

Twenty-eight young virgin Wistar female rats, weighing $110 \pm 10 \mathrm{~g}$, were obtained from the animal house of the National Research Center in Egypt. Ethical approval was obtained from the Institutional Animal Care and Use Committee of National Research Center, Egypt. All animal procedures were in accordance with the guidelines and instructions of Institutional Animal Care and Use Committee of National Research Center. All efforts were taken to minimize the suffering and number of animals used. The rats were acclimatized in the laboratory conditions for a period of 1 week before being used in the experiment under observation to exclude any intercurrent infection. They were marked and kept in autoclavable polypropylene cages $(25 \times 40 \times 25 \mathrm{~cm}$; seven rats in a cage) with good aerated covers at normal atmospheric temperature $\left(25 \pm 5^{\circ} \mathrm{C}\right)$ and at normal daily $12 \mathrm{~h}$

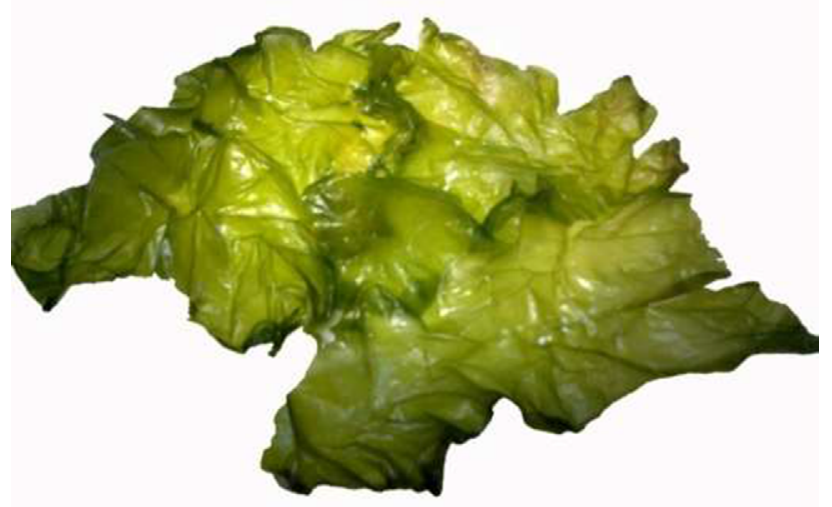

Figure I Ulva lactuca (sea lettuce). 
dark/light cycle. They were fed with commercial food pellets which were formulated to satisfy the recommended needs stated by the National Research Council and provided with tap water ad libitum. Ethical approval was obtained from the Institutional Animal Care and Use Committee of National Research Center, Egypt. The rats were monitored daily for general well-being by close scrutiny for morbidity. The cages were cleaned and water was changed every second day. The rats were weighed before the starting of the experiment and individual weights were recorded. They were weighed individually each week during the course of the experiment.

\section{U. lactuca polysaccharides extraction}

Polysaccharides were extracted from U. lactuca by the technique described previously ${ }^{13-15}$ with some modifications. Briefly, $50 \mathrm{~g}$ of air shade dried algae were roughly cut and boiled in $500 \mathrm{~mL}$ of distilled water at $100^{\circ} \mathrm{C}$ for $3 \mathrm{~h}$. The slurry was separated by gauze and filtered. The filtrate was dialyzed against tap water for $48 \mathrm{~h}$ and then concentrated to $\sim 100 \mathrm{~mL}$ under reduced pressure using rotary evaporator. Then, the concentrated filtrate was precipitated using equal volume of $95 \%$ ethanol. The mixture was allowed to stand overnight at room temperature. The precipitate was collected and washed twice with absolute ethanol, then dried at $50^{\circ} \mathrm{C}$. The crude polysaccharide extract was stored at $4^{\circ} \mathrm{C}$ until used.

\section{Acute toxicity study of U. lactuca polysaccharides}

By increasing the dose up to $3 \mathrm{~g}$ ulvan polysaccharides administered by gastric tube $/ \mathrm{kg}$ body weight (b.wt) rats, no mortality was observed during the first $48 \mathrm{~h}$ after administration.

\section{Preparation of solutions}

\section{Ulvan polysaccharide solution}

The orally administered dose of ulvan polysaccharides, $50 \mathrm{mg} / \mathrm{kg}$ b.wt, which is farther far from the higher tested dose in acute toxicity study ( $3 \mathrm{~g} / \mathrm{kg} \mathrm{b.wt)}$ which produced no mortality, was prepared by dissolving each $50 \mathrm{mg}$ in $5 \mathrm{~mL}$ of boiled sterilized saline solution ( $1 \mathrm{wt} / \mathrm{v})$.

\section{DMBA treatment}

To prepare a dose of $25 \mathrm{mg}$ of DMBA $/ \mathrm{kg}$ b.wt rats, $25 \mathrm{mg}$ of DMBA (powder) was dissolved in $5 \mathrm{~mL}$ of filter-sterilized heavy mineral oil. ${ }^{16}$

\section{Experimental design (animal grouping)}

After an adaptation period of 1 week, the animals were divided into four main groups, each of seven rats:

\section{Group I: Normal control group}

The animals received a single dose of mineral oil $(5 \mathrm{~mL} /$ $\mathrm{kg} \mathrm{b.wt)} \mathrm{through} \mathrm{oral} \mathrm{administration} \mathrm{and} \mathrm{were} \mathrm{administered}$ sterilized $0.9 \%$ saline $(5 \mathrm{~mL} / \mathrm{kg}$ b.wt) for 10 weeks (every other day).

\section{Group 2: Normal group treated with ulvan polysaccharides}

The animals received single dose of mineral oil $(5 \mathrm{~mL} / \mathrm{kg}$ b.wt) through oral administration and were administered ulvan polysaccharides dissolved in $5 \mathrm{~mL}$ of sterilized $0.9 \%$ saline at a dose level of $50 \mathrm{mg} / \mathrm{kg}$ b.wt for 10 weeks (every other day).

\section{Group 3: DMBA-administered control group}

The animals were subjected to a single dose of $25 \mathrm{mg}$ DMBA (dissolved in $5 \mathrm{~mL}$ of mineral oil)/kg b.wt as described previously. ${ }^{17-19}$ They were also administered $0.9 \%$ saline $(5 \mathrm{~mL} / \mathrm{kg}$ b.wt) for 10 weeks (every other day).

\section{Group 4: DMBA-administered group treated with ulvan polysaccharides}

The animals were subjected to a single dose through oral administration of $25 \mathrm{mg} / \mathrm{kg}$ b.wt of DMBA dissolved in $5 \mathrm{~mL}$ of mineral oil and received ulvan polysaccharides $(50 \mathrm{mg} /$ $\mathrm{kg}$ b.wt every other day) dissolved in $5 \mathrm{~mL}$ of sterilized $0.9 \%$ saline for 10 weeks.

All administrations were performed by intragastric gavages at $10-12$ AM.

\section{Sampling Blood sampling}

At the end of the experiment, after 10 weeks, the animals were fasted overnight for $12 \mathrm{~h}$ and then were subjected to diethyl ether anesthesia. Blood samples were collected from carotid artery and left for $1 \mathrm{~h}$ at room temperature, then centrifuged at $3000 \mathrm{rpm}$ for $15 \mathrm{~min}$ at $4^{\circ} \mathrm{C}$ in order to separate the serum which was kept at $-20^{\circ} \mathrm{C}$ until being used for biochemical assays.

\section{Tissue sampling}

Immediately after the animals were sacrificed and dissection, breasts of each animal were quickly excised, washed with normal saline, blotted with filter paper, and weighed to adjust doses according to body weight. Breasts were immediately fixed in 10\% neutral buffered formalin, and then stored for $24 \mathrm{~h}$ for paraffin embedding and later for histological and histopathological characterization and for 
immunohistochemical studies. The other set of breast sections were placed in ice-cold saline $(0.9 \mathrm{~N} \mathrm{NaCl})$ and then were homogenized in radioimmunoprecipitation assay buffer (20 mM Tris pH 7.5, 0.1\% SDS, $150 \mathrm{mM} \mathrm{NaCl,} \mathrm{0.5 \%} \mathrm{sodium}$ deoxycholate, and 1\% Nonidet P-40). The homogenate was centrifuged at $10,000 \mathrm{rpm}$ for $10 \mathrm{~min}$ at $4^{\circ} \mathrm{C}$ using cooling centrifuge, and the supernatant was prepared for analysis.

\section{Histopathological examination}

After the preparation of breast tissue samples as mentioned previously in tissue sampling, fixed breast tissue samples were embedded after dehydration in paraffin wax, sectioned at a thickness of $5 \mu \mathrm{m}$, and stained with hematoxylin and eosin (H\&E). Preparation, processing, and staining were performed in the histopathology lab, the Department of Pathology, Faculty of Veterinary Medicine, Beni-Suef University, Egypt.

\section{Immunohistochemical detection of p53 and bcl-2} expression in rat breast tissue

Immunohistochemical (IHC) staining techniques and staining procedure for p53 and bcl-2 were carried out according to Ahmed and Ahmed. ${ }^{11}$

\section{Cytotoxic activity of U. Lactuca polysaccharides on} human breast cancer cell lines (MCF-7)

$\mathrm{MCF}-7$ frozen in liquid nitrogen $\left(-180^{\circ} \mathrm{C}\right)$ was obtained from the American Type Culture Collection (Manassas, VA, USA). The tumor cell lines were maintained and the antiproliferative effect was assessed in the Pharmacology Unit, Department of Cancer Biology, National Cancer Institute, Cairo, Egypt, by serial subculturing. The method was carried out according to Skehan et al. ${ }^{20}$

\section{Assays of serum tumor necrosis factor- $\alpha$ (TNF- $\alpha$ ) and NO levels}

Serum level of TNF- $\alpha$ was quantified by enzyme-linked immunosorbent assay using commercially available matched paired antibodies according to the instructions of R\&D Systems Inc. (Minneapolis, MN, USA). Nitrite accumulation was used as an indicator for NO production using a microplate assay based on the Griess reaction. ${ }^{21}$

\section{Assays of breast oxidative stress and antioxidant defense markers}

Breast lipid peroxidation, an indicator of oxidative stress, was measured according to the method proposed by Preuss et $\mathrm{al}^{22}$ by measuring malondialdehyde (MDA) level using reagents prepared in the laboratory. Breast glutathione (GSH) content and glutathione-S-transferase (GST) activity were determined according to the methods of Beutler et $\mathrm{al}^{23}$ and Mannervik and Guthenberg, ${ }^{24}$ respectively, by using reagents prepared in the laboratory. Glutathione reductase (GR), glutathione peroxidase (GPx), and catalase (CAT) activities were assayed spectrophotometrically by the methods of Goldberg and Spooner, ${ }^{25}$ Paglia and Valentine, ${ }^{26}$ and Aebi, ${ }^{27}$ respectively, by using reagent kits purchased from Biodiagnostic (Cairo, Egypt).

\section{Statistical analysis of data}

The data were analyzed using one-way analysis of variance followed by LSD test to compare various groups with each other using PC-STAT program (University of Georgia) coded by Rao et al. ${ }^{28}$ Results were expressed as mean \pm standard error (SE), and values of $P>0.05$ were considered nonsignificantly different, whereas $P<0.05$ and $P<0.01$ were considered significant and highly significant, respectively. $F$-probability shows the general effect between groups.

\section{Results \\ Histopathological changes in breast tissues}

The effect of $U$. lactuca polysaccharides on breast tissues of DMBA-administered rats was evaluated by histopathological examination of the breast tissue sections stained with H\&E. The histological sections depicted in Figure 2 show mammary gland of normal control rats with normal acini lined with cuboidal epithelial cells. In addition, Figure 3 shows breast section of normal control group exhibiting normal lobuloalveolar unit. The breast of normal rats treated with

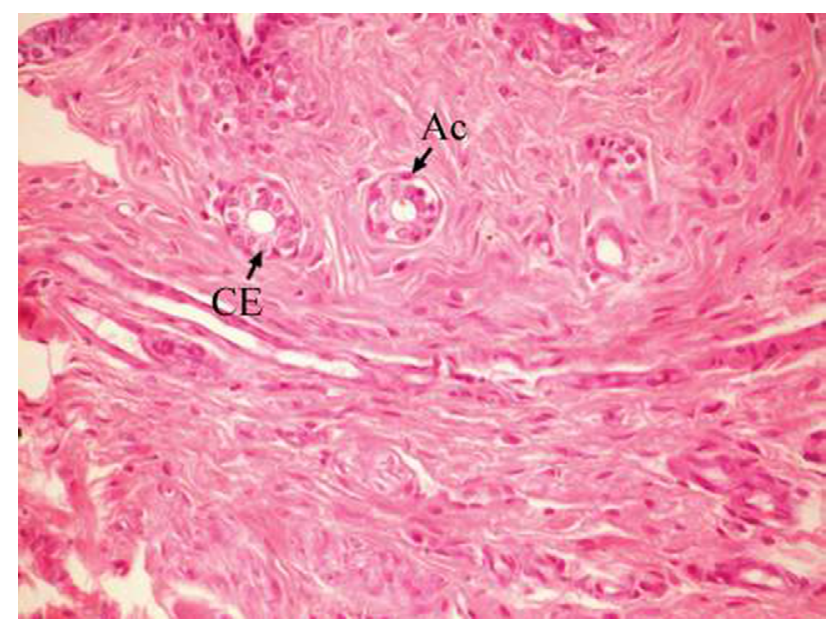

Figure 2 Photomicrograph of breast section of normal control rat showing normal acini $(A c)$ lined with CEs ( $H$ and $E, \times 400)$.

Abbreviations: $\mathrm{CE}$, cuboidal epithelial cell; $\mathrm{H}$ and $\mathrm{E}$, hematoxylin and eosin. 
ulvan polysaccharides exhibited normal structure with normal lobuloalveolar unit (Figure 4), and it was noted that mammary acini was lined with cuboidal epithelium.

On the other hand, the single-dose administration of DMBA produced histopathological changes in breast tissues in DMBA-administered control rats showing cystic dilatation of duct with intraluminal necrotic materials (Figure 5), papillary cyst adenoma (Figure 6), and hyperplasia of ductal epithelial lining with intraluminal necrotic materials with calcifications (Figure 7).

The breast of DMBA-administered rats treated with ulvan polysaccharides exhibited apparent normal duct, normal acini with cuboidal epithelial lining (Figure 8), and normal lobuloalveolar unit (Figure 9).

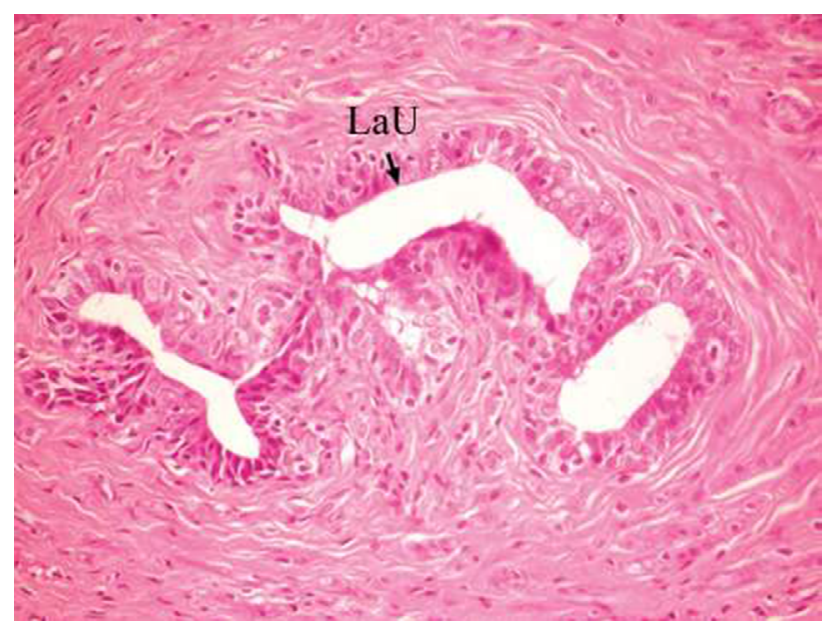

Figure 3 Photomicrograph of breast section of normal control rat showing normal $\mathrm{LaU}(\mathrm{H}$ and $\mathrm{E}, \times 400)$.

Abbreviations: $\mathrm{LaU}$, lobuloalveolar unit; $\mathrm{H}$ and $\mathrm{E}$, hematoxylin and eosin.

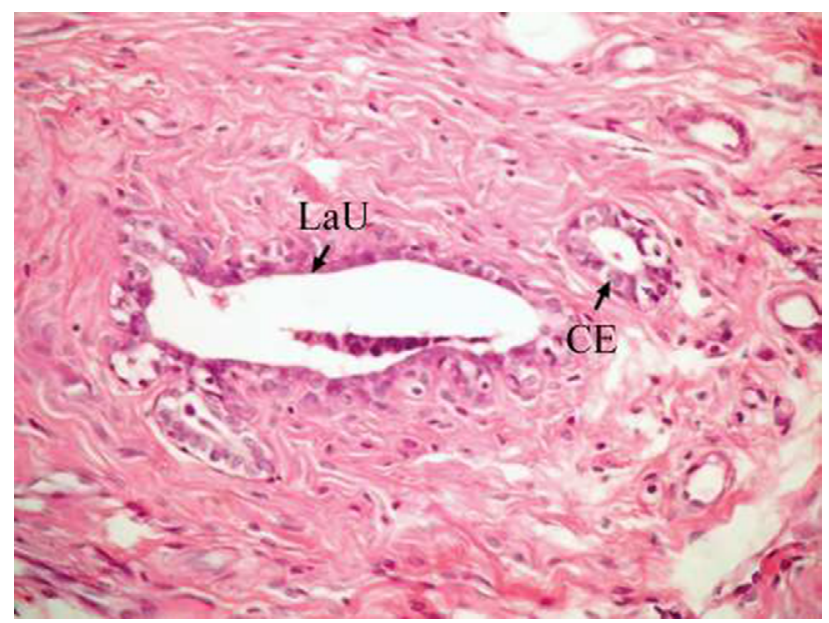

Figure 4 Photomicrograph of breast section of normal rat treated with ulvan polysaccharides showing normal LaU. Notice that mammary acini are lined with $\mathrm{CE}$ ( $\mathrm{H}$ and $\mathrm{E}, \times 400)$.

Abbreviations: LaU, lobuloalveolar unit; $\mathrm{CE}$, cuboidal epithelial cell; $\mathrm{H}$ and $\mathrm{E}$, hematoxylin and eosin.

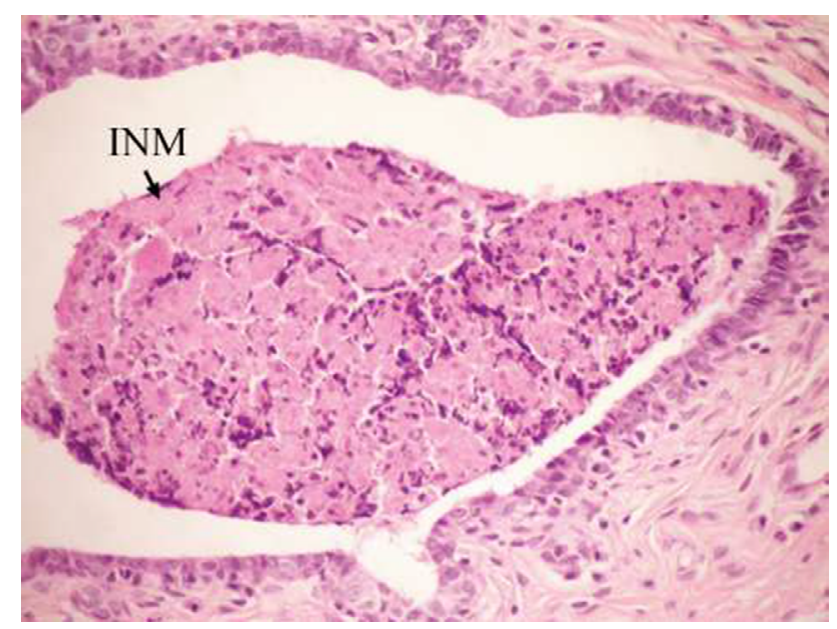

Figure 5 Photomicrograph of breast section of DMBA-administered control rat showing cystic dilatation of duct with INM $(\mathrm{H}$ and $\mathrm{E}, \times 400)$.

Abbreviations: DMBA, 7,12-dimethylbenz[a]anthracene; INM, intraluminal necrotic material; $\mathrm{H}$ and $\mathrm{E}$, hematoxylin and eosin.

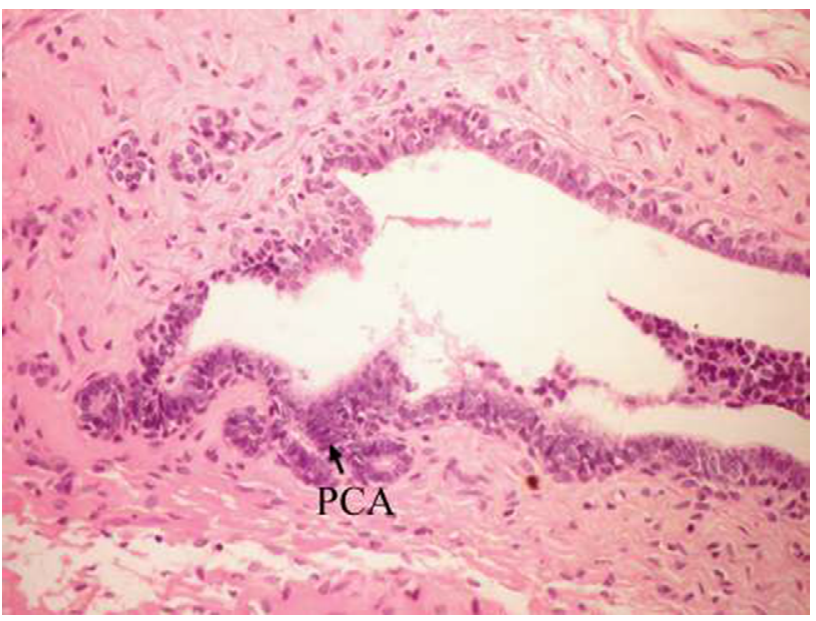

Figure 6 Photomicrograph of breast section of DMBA-administered control rat showing PCA ( $\mathrm{H}$ and $\mathrm{E}, \times 400)$.

Abbreviations: DMBA, 7,12-dimethylbenz[a]anthracene; PCA, papillary cyst adenoma; $\mathrm{H}$ and $\mathrm{E}$, hematoxylin and eosin.

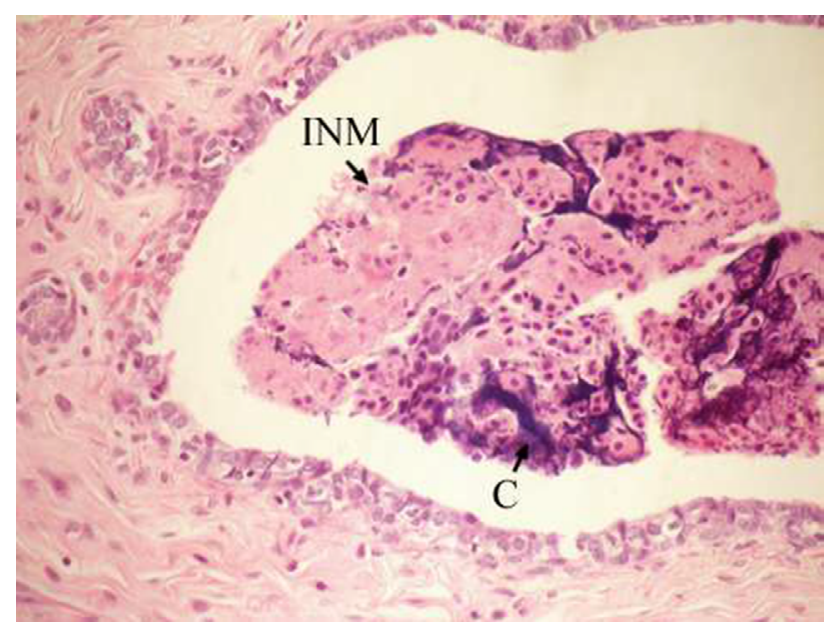

Figure 7 Photomicrograph of breast section of DMBA-administered control rat showing hyperplasia of ductal epithelial lining with INM and calcifications (C) $(H$ and $E, \times 400)$.

Abbreviations: DMBA, 7,12-dimethylbenz[a]anthracene; INM, intraluminal necrotic material; $\mathrm{H}$ and $\mathrm{E}$, hematoxylin and eosin. 


\section{Effects on p53 and bcl-2 expression in rat breast}

The effect of $U$. lactuca polysaccharides on tumor suppressor protein $\mathrm{p} 53$ and anti-apoptotic mediator bcl-2 was examined

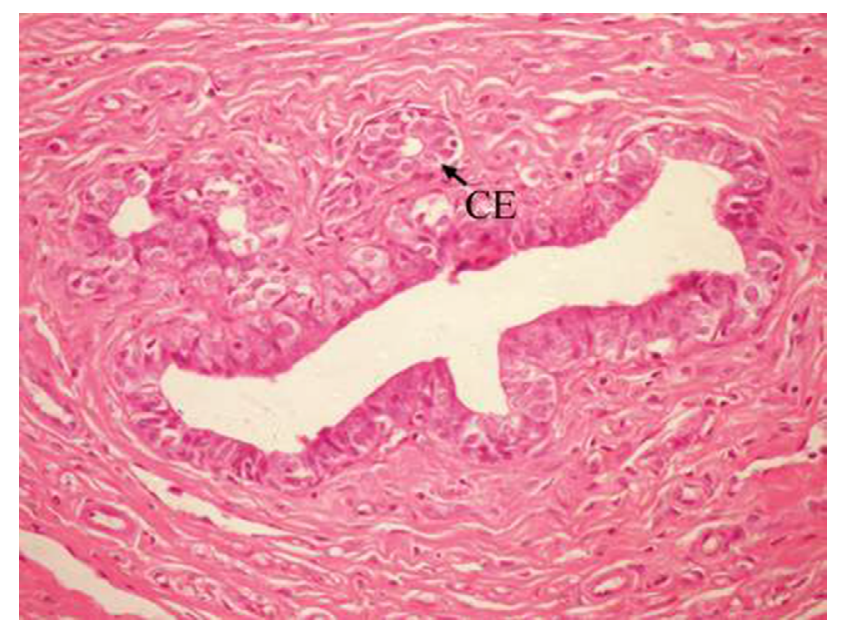

Figure 8 Photomicrograph of breast section of DMBA-administered group rat treated with ulvan polysaccharides showing apparent normal duct and acini with $C E$ lining $(\mathrm{H}$ and $\mathrm{E}, \times 400)$.

Abbreviations: DMBA, 7,12-dimethylbenz[a]anthracene; CE, cuboidal epithelial cell; $\mathrm{H}$ and $\mathrm{E}$, hematoxylin and eosin.

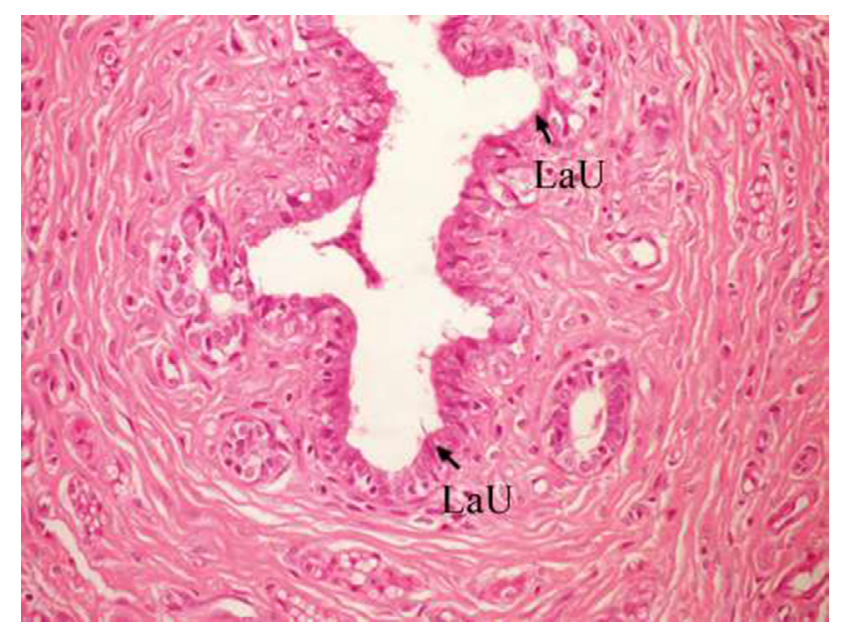

Figure 9 Photomicrograph of breast section of DMBA-administered group rat treated with ulvan polysaccharides showing normal acini, normal duct, and normal $\mathrm{LaU}(\mathrm{H}$ and $\mathrm{E}, \times 400)$.

Abbreviations: DMBA, 7,12-dimethylbenz[a]anthracene; LaU, lobuloalveolar unit; $\mathrm{H}$ and $\mathrm{E}$, hematoxylin and eosin. by immunohistochemical techniques through the intensity of immunoreactivity (Figures 10-17).

The photomicrographs of immunohistochemically stained breast tissue sections revealed that the administration of ulvan polysaccharides to normal rats produced a moderate increase in the amount of $\mathrm{p} 53$ expressed (Figure $11 \mathrm{~A}-\mathrm{C}$ ) as compared to the breast tissue of normal control (Figure 10A-C). On the other hand, the amount of p53 was remarkably decreased in DMBA-administrated rats (Figure $12 \mathrm{~A}-\mathrm{C}$ ) as compared to the normal control. The treatment of DMBA-administered rats with ulvan polysaccharides successfully increased the amount of expressed p53 (Figure $13 \mathrm{~A}-\mathrm{C}$ ) as compared to DMBA-administered control rats (Figure 12A-C).

The photomicrographs of immunohistochemically stained breast sections revealed that the administration of ulvan polysaccharides to normal rats produced more or less no change in the amount of expressed bcl-2 (Figure 15A-C) as compared to breast tissue of normal control (Figure 14A and $\mathrm{B})$. On the other hand, the amount of bcl-2 was potentially increased in DMBA-administered rats (Figure 16A-C) as compared to the normal control. The treatment of DMBA-administered rats with ulvan polysaccharides potentially decreased the elevated amount of expressed bcl-2 (Figure 17A-C) as compared to DMBA-administered control rats (Figure 16A-C).

\section{Cytotoxicity effects on breast carcinoma cell line (MCF-7)}

Figure 18 revealed a marked stepwise gradual decrease in the survival percent of breast carcinoma cell lines (MCF-7) as the concentration of ulvan polysaccharides increased from 25 to $200 \mu \mathrm{g} / \mathrm{mL}$ in culture incubation medium. The $\mathrm{IC}_{50}$ was $224.716 \mu \mathrm{g} / \mathrm{mL}$.

\section{Effect on serum TNF- $\alpha$ and NO concentrations}

The effect of ulvan polysaccharides on serum TNF- $\alpha$ and level in normal and DMBA-administered rats is shown in
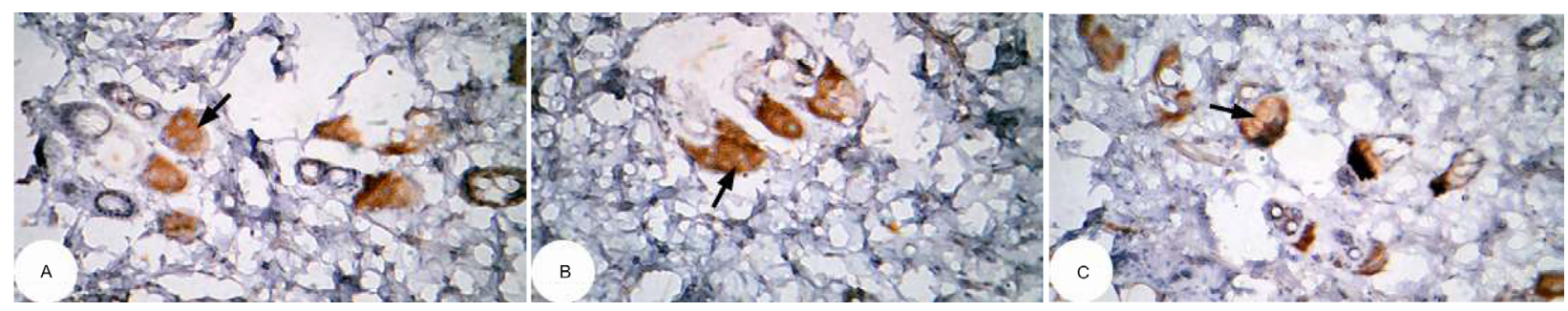

Figure 10 Photomicrographs of immunohistochemically stained breast tissue sections showing apoptotic marker, p53 expression (indicated by the arrows) in normal control rats $(\mathbf{A}, \mathbf{B}$, and $\mathrm{C} ; \times 400)$.

Note: $\mathbf{A}, \mathbf{B}$, and $\mathbf{C}$ are different sections from more than one rat of the same group. 

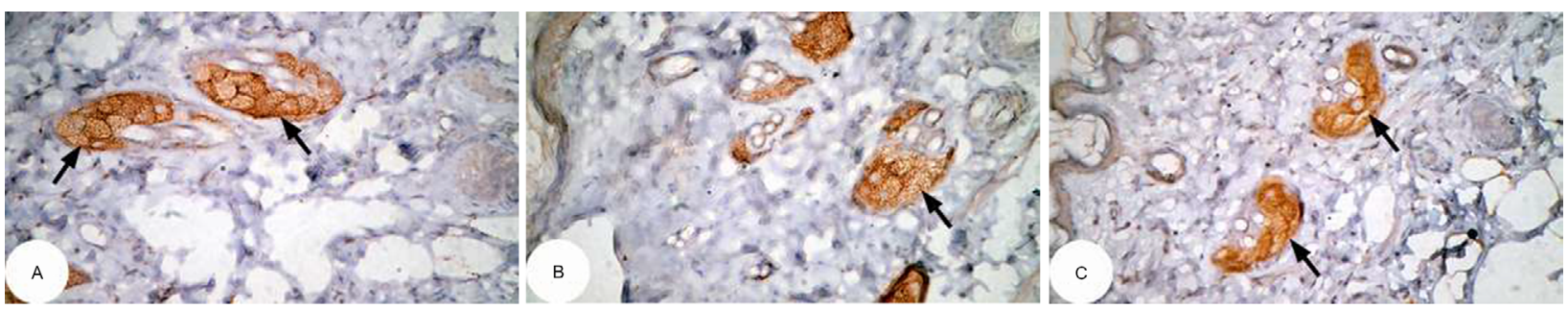

Figure II Photomicrographs of immunohistochemically stained breast tissue sections showing the effect of Ulva lactuca polysaccharides on apoptotic marker p53 expression (indicated by the arrows) $(\mathbf{A}, \mathbf{B}$, and $\mathbf{C} ; \times 400)$.

Note: A, B, and $\mathbf{C}$ are different sections from more than one rat of the same group.

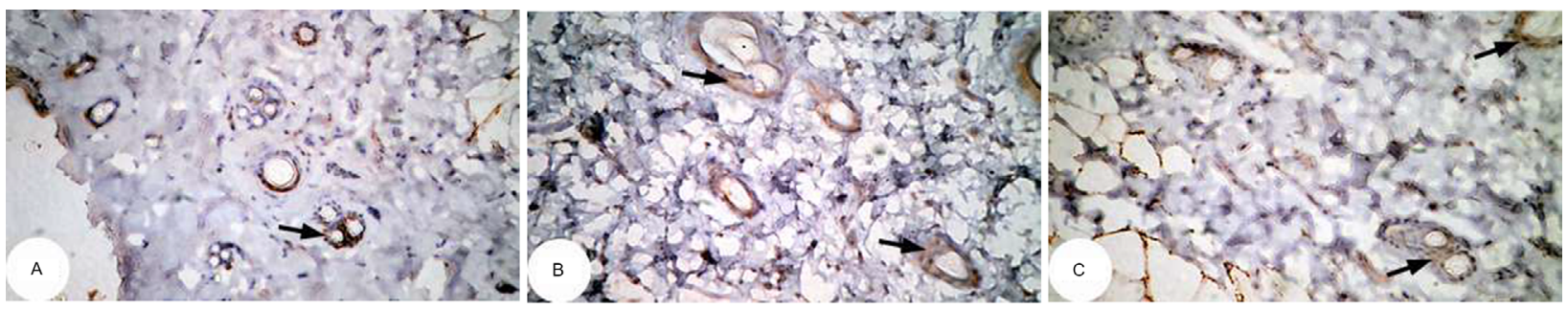

Figure 12 Photomicrographs of immunohistochemically stained breast tissue sections showing the effect of DMBA on apoptotic marker p53 expression (indicated by the arrows) (A, B, and C; $\times 400)$.

Abbreviation: DMBA, 7,12-dimethylbenz[a]anthracene.

Note: A, B, and $\mathbf{C}$ are different sections from more than one rat of the same group
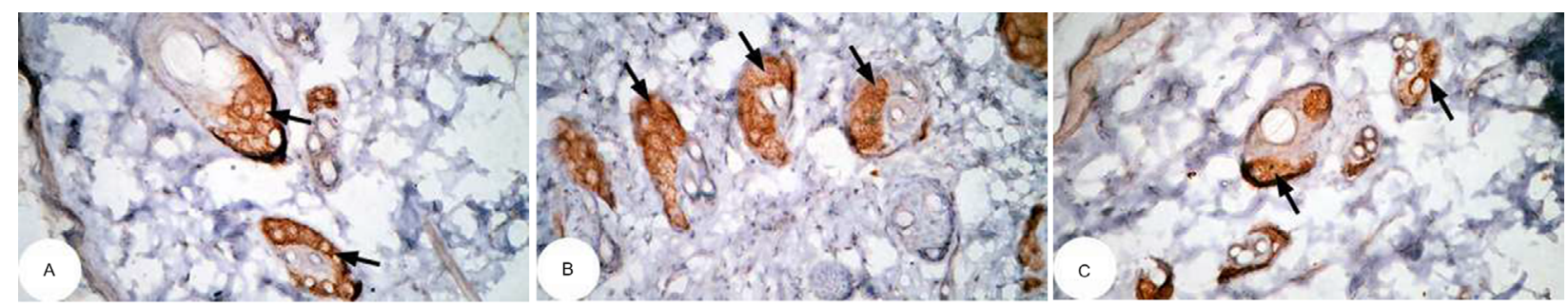

Figure 13 Photomicrographs of immunohistochemically stained breast tissue sections showing the effect of Ulva lactuca polysaccharides on apoptotic marker p53 expression (indicated by the arrows) in DMBA-administered rats (A, B, and C; $\times 400$ ).

Abbreviation: DMBA, 7, 12-dimethylbenz[a]anthracene.

Note: A, B, and C are different sections from more than one rat of the same group.
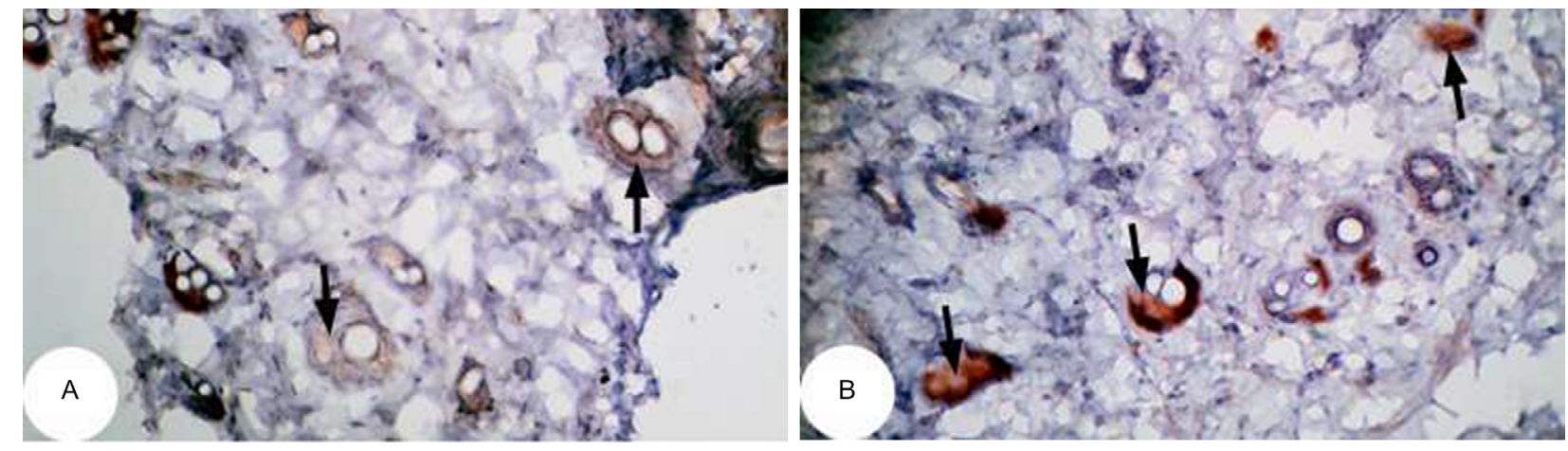

Figure 14 Photomicrographs of immunohistochemically stained breast tissue sections showing antiapoptotic marker, bcl-2 expression (indicated by the arrows) in normal control rats (A and $\mathbf{B} ; \times 400)$.

Note: $\mathbf{A}$ and $\mathbf{B}$ are different sections from more than one rat of the same group.

Table 1. The administration of ulvan polysaccharides to normal rats produced no significant change $(P>0.05)$ of TNF- $\alpha$ and NO levels. On the other hand, the single-dose administration of DMBA produced a highly significant increase $(P<0.01)$ in both the concentrations. The treatment of DMBA-administered rats with ulvan polysaccharides succeeded in decreasing the elevated levels of serum TNF- $\alpha$ and NO levels $(P<0.01)$ recording percentage decreases of $33.95 \%$ and $36.86 \%$, respectively, as compared to the DMBA-administered control. 


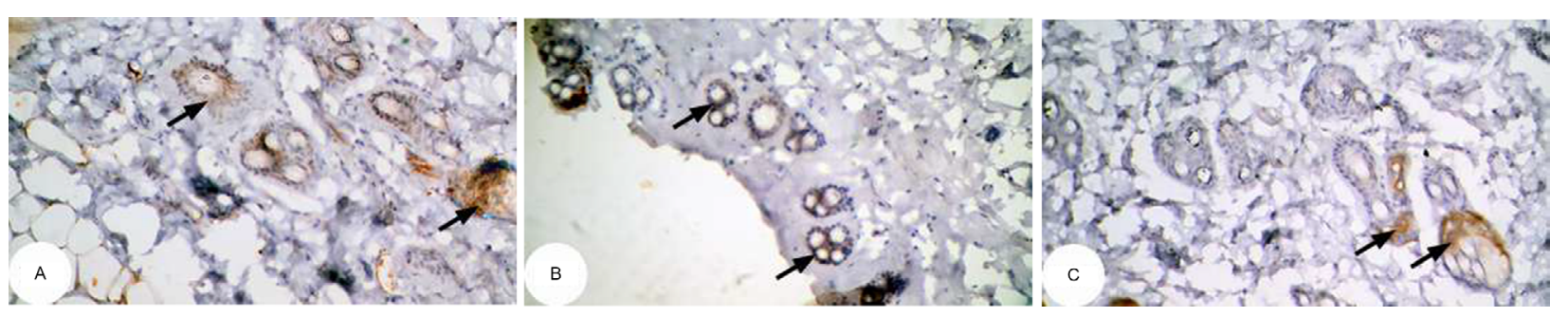

Figure 15 Photomicrographs of immunohistochemically stained breast tissue sections showing the effect of Ulva lactuca polysaccharides on antiapoptotic marker bcl-2 expression (indicated by the arrows) $(\mathbf{A}, \mathbf{B}$, and $\mathbf{C} ; \times 400)$.

Note: $\mathbf{A}, \mathbf{B}$, and $\mathbf{C}$ are different sections from more than one rat of the same group.

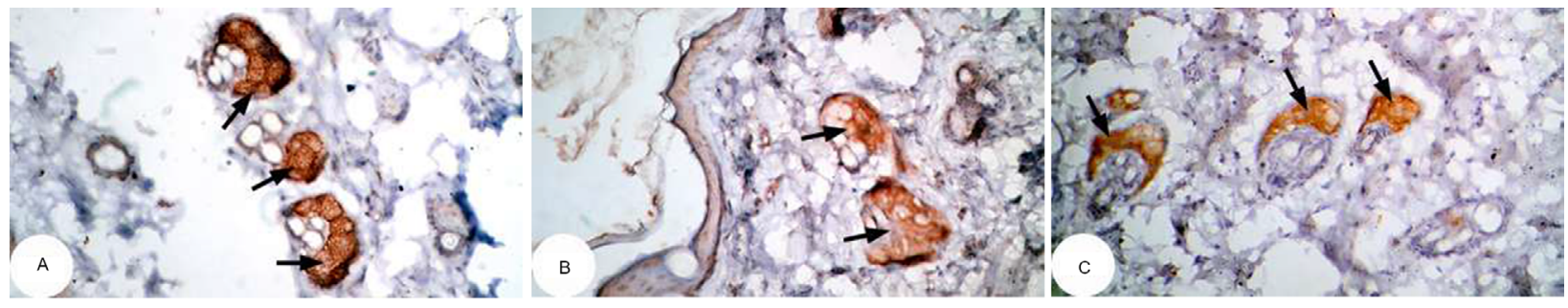

Figure 16 Photomicrographs of immunohistochemically stained breast tissue sections showing the effect of DMBA on antiapoptotic marker bcl-2 expression (indicated by the arrows) (A, B, and C; $\times 400)$.

Note: $\mathbf{A}, \mathbf{B}$, and $\mathbf{C}$ are different sections from more than one rat of the same group.

Abbreviation: DMBA, 7,12-dimethylbenz[a]anthracene.

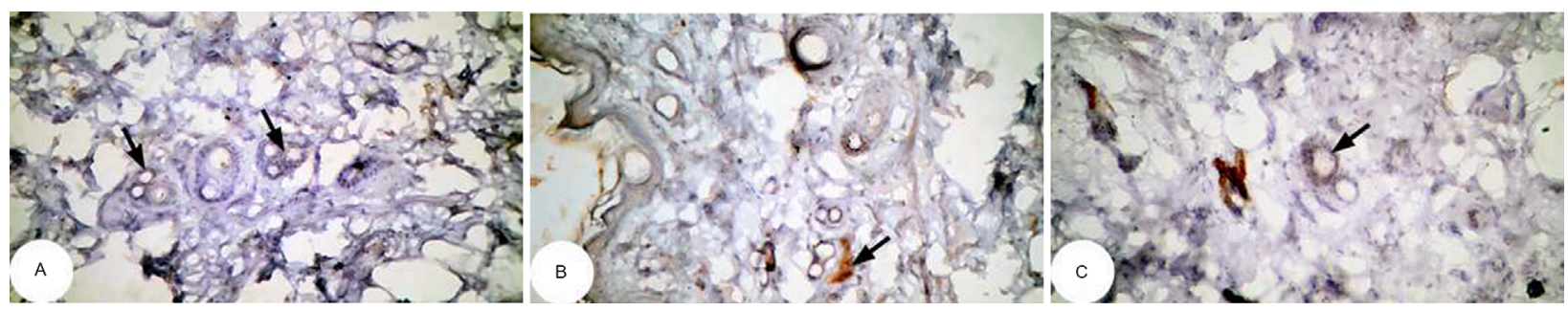

Figure 17 Photomicrographs of immunohistochemically stained breast tissue sections showing the effect of Ulva lactuca polysaccharides on antiapoptotic marker bcl-2 expression (indicated by the arrows) in DMBA-administered rats (A, B, and C; $\times 400)$.

Note: $\mathbf{A}, \mathbf{B}$, and $\mathbf{C}$ are different sections from more than one rat of the same group.

Abbreviation: DMBA, 7,12-dimethylbenz[a]anthracene.

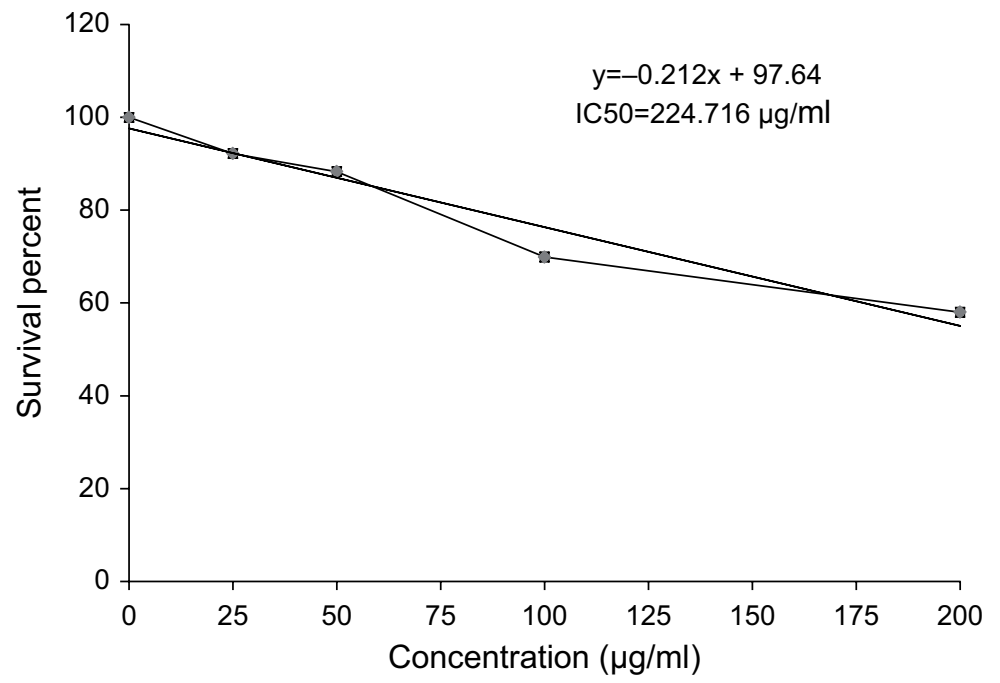

Figure 18 Cytotoxic effect of Ulva lactuca polysaccharides on human breast cancer cell line (MCF-7). 
Table I The effect of Ulva lactuca polysaccharide administration on serum tumor necrosis factor-alpha (TNF- $\alpha$ ) and nitric oxide (NO) concentrations in DMBA-treated rats

\begin{tabular}{|c|c|c|c|c|}
\hline Parameters & TNF- $\alpha(\mathrm{pg} / \mathrm{mL})$ & $\%$ change & $\begin{array}{l}\text { NO concentration } \\
(\mu \mathrm{mol} / \mathrm{L})\end{array}$ & $\%$ change \\
\hline Normal control & $204.0 \pm 3.82^{b}$ & - & $4.90 \pm 1.32^{c}$ & - \\
\hline Normal treated with ulvan polysaccharides & $204.7 \pm 6.48^{b}$ & +0.35 & $5.06 \pm 1.50^{c}$ & +3.12 \\
\hline DMBA-administered control & $252.9 \pm 6.60^{\mathrm{a}}$ & +23.95 & $\left.|5.60 \pm| .5\right|^{\mathrm{a}}$ & +218.15 \\
\hline DMBA-administered group treated with ulvan polysaccharides & $167.0 \pm 5.54^{c}$ & -33.95 & $9.85 \pm 0.99^{b}$ & -36.86 \\
\hline LSD at the $5 \%$ level & 16.69 & & 3.93 & \\
\hline LSD at the I\% level & 22.62 & & 5.32 & \\
\hline
\end{tabular}

Notes: Values are expressed as mean \pm standard error (SE) of seven rats per group. Means, which share the same superscript symbol(s), are not significantly different $(P>0.05)$. I) If the difference between two means is higher than the value of LSD at the $5 \%$ level, the effect will be significant $(P<0.05)$. 2$)$ If the difference between two means is higher than the value of LSD at the $1 \%$ level, then the effect will be highly significant $(P<0.01)$. \% changes were calculated by comparing normal rats treated with ulvan polysaccharides and DMBA-administered control with normal control group; and DMBA-administered rats treated with ulvan polysaccharides with DMBA-administered control. LSD (least significant difference) between means.

Abbreviation: DMBA, 7,12-dimethylbenz[a]anthracene.

Table 2 The effect of Ulva lactuca polysaccharides administration on lipid peroxidation ( $\mathrm{nmol}$ MDA/l00 $\mathrm{mg}$ tissue/h) in breast tissue homogenate

\begin{tabular}{|c|c|c|}
\hline Parameters & $\begin{array}{l}\text { Lipid peroxidation } \\
\text { (nmol MDA/I } 00 \\
\text { mg tissue/h) }\end{array}$ & $\%$ change \\
\hline Normal control & $29.57 \pm 1.07^{c}$ & - \\
\hline $\begin{array}{l}\text { Normal treated with ulvan } \\
\text { polysaccharides }\end{array}$ & $36.29 \pm 0.52^{b}$ & +22.73 \\
\hline DMBA-administered control & $67.14 \pm 1.77^{\mathrm{a}}$ & +126.92 \\
\hline $\begin{array}{l}\text { DMBA-administered group treated } \\
\text { with ulvan polysaccharides }\end{array}$ & $32.7 I \pm 3.37^{b c}$ & -51.28 \\
\hline LSD at the $5 \%$ level & 5.818 & \\
\hline LSD at the I\% level & 7.884 & \\
\hline
\end{tabular}

Notes: Values are expressed as mean \pm standard error (SE) of seven rats per group. Means, which share the same superscript symbol(s), are not significantly different $(P>0.05)$. I) If the difference between two means is higher than the value of LSD at the $5 \%$ level, the effect will be significant $(P<0.05)$. 2) If the difference between two means is higher than the value of LSD at the $1 \%$ level, then the effect will be highly significant $(P<0.01)$. \% changes were calculated by comparing normal rats treated with ulvan polysaccharides and DMBA-administered control with normal control group; and DMBA-administered rats treated with ulvan polysaccharides with DMBA-administered control. LSD (least significant difference) between means.

Abbreviations: DMBA, 7,12-dimethylbenz[a]anthracene; MDA, malondialdehyde bis diethyl acetal.

\section{Effect on breast lipid peroxidation}

The effect of ulvan polysaccharides on breast MDA level which expresses the lipid peroxidation in normal and DMBA-administered rats is shown in Table 2. The administration of ulvan polysaccharides to normal rats increased $(P<0.05)$ lipid peroxidation. The single-dose administration of DMBA produced a highly significant increase $(P<0.01)$ of lipid peroxidation; recording an increase of $126.92 \%$ as compared to normal control. On the other hand, the treatment of DMBA-administered rats with ulvan polysaccharides significantly ameliorated to significantly ameliorate $(P<0.01)$ the elevated rates of lipid peroxidation, recording a decrease of $51.28 \%$ as compared to the DMBA-administered control.

\section{Effects on breast GSH content and antioxidant enzyme activities}

The effects of ulvan polysaccharides on breast GSH concentration and antioxidant enzyme activities in normal and DMBA-administrated rats are shown in Table 3. The administration of ulvan polysaccharides to normal rats produced a detectable decrease in GSH concentration as compared to normal control. The single-dose administration of DMBA produced a highly significant decrease $(P<0.01)$ in $\mathrm{GSH}$ concentration; the recorded decrease of percentage change was $39.16 \%$ as compared to normal control. On the other hand, the treatment of DMBA-administered rats with ulvan polysaccharides succeeded in increasing $(P<0.05 ; 26.60 \%)$ the diminished GSH content as compared to the DMBAadministered control.

The activities of antioxidant enzymes, including GR, GST, GPx, and CAT, were markedly decreased in normal rats treated with ulvan polysaccharides as compared with the normal control recording changes of $-10.14 \%,-9.94 \%$, $-16.26 \%$, and $-50.71 \%$, respectively. On the other hand, DMBA administration produced a highly significant decrease of these enzyme activities $(P<0.01)$. CAT followed by GPx seemed to be the most affected tested enzymes since their percentage decreases were $84.86 \%$ and $75.61 \%$, respectively, as compared to the normal control. The treatment of DMBAadministered rats with ulvan polysaccharides successfully improved the suppressed antioxidant enzyme activities; the recorded increases were $35.90 \%, 209.30 \%, 121.10 \%$, and $334.64 \%$, respectively, for GR, GST, GPx, and CAT activities in comparison with the DMBA-administered control rats. Moreover, the effect of ulvan polysaccharides on GST, GPx, and CAT of DMBA-administered rats was highly significant $(P<0.01)$. 


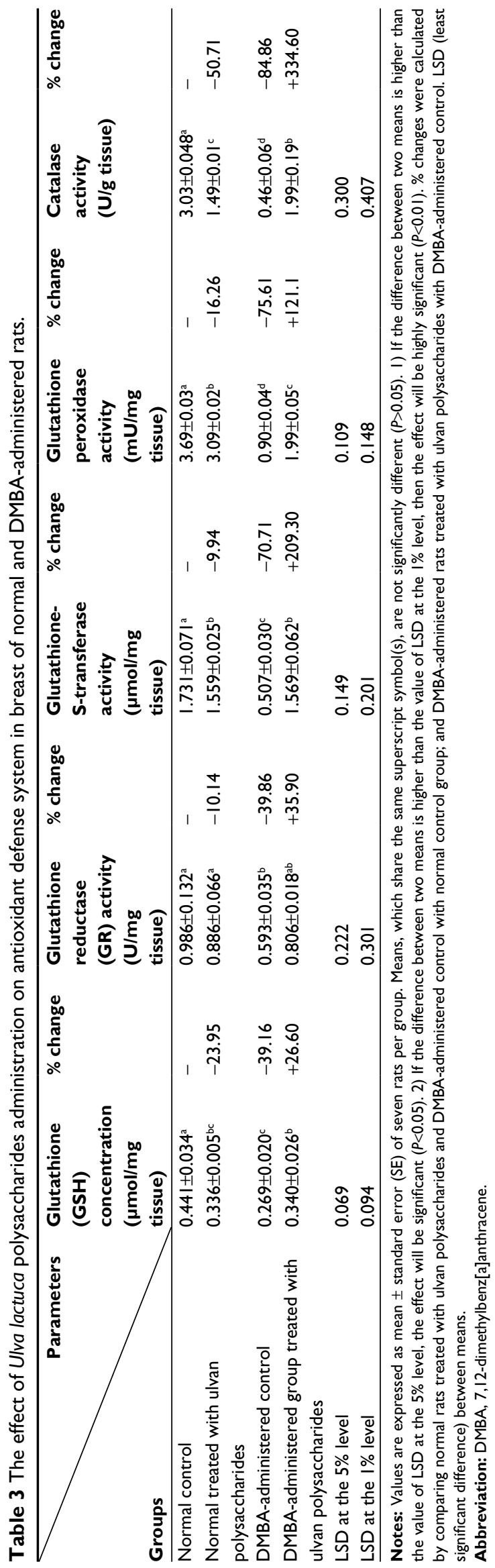

\section{Discussion}

In the present study, DMBA-induced rat mammary carcinogenesis at the level of initiation and promotion that assessed histopathologically and MCF-7 in vitro were used for the evaluation of the activities of $U$. lactuca polysaccharides as cancer chemopreventive and antiproliferative agents.

Animal experimental systems are particularly useful for the study of human mammary carcinogenesis. Since the rat mammary gland shows a high susceptibility to develop neoplasms, which closely mimic human breast cancer, they have been selected in comparison with other animal models. ${ }^{29}$

In the present study, DMBA is used as a mammary carcinogenic agent. After 10 weeks of a single oral dose of $25 \mathrm{mg} / \mathrm{kg}$ b. wt of DMBA, papillary cyst adenoma, hyperplasia of ductal epithelial lining, cystic dilatation of ducts, and intraluminal necrotic materials with calcifications were found. Thus, the present study goes parallel with several previous publications which stated that DMBA induced mammary carcinogenesis in rats. ${ }^{30-33}$ As indicated from previous publications, the mechanism of carcinogenic action of DMBA involves the formation of ultimate carcinogenic metabolite, DMBA-3,4-diol-1,2-epoxide (DMBA-DE), which increases oxidative stress, binds to DNA to form DNA adducts, causes DNA damage, and produces immunotoxicity. ${ }^{34,35}$

The administration of ulvan polysaccharides to DMBAtreated rats for a period of 10 weeks successfully prevented the DMBA-induced histological alterations and carcinogenic lesions. This evidence was confirmed by breast tissue sections of DMBA-administered rats, treated with ulvan polysaccharides, which showed apparent normal duct, normal acini with cuboidal epithelial lining, and normal lobuloalveolar units. In accordance with these results, previous studies ${ }^{36,37}$ revealed that ulvan polysaccharides have great amelioration in all histological lesions in liver and kidney tissues of rats. Moreover, Ahmed and Ahmed ${ }^{11}$ reported that ulvan polysaccharides inhibited Ehrlich ascites cell proliferation in EAC-bearing mouse model. They stated that some EAC cells were degenerated, and many others exhibited phenotypic apoptotic signs including cell shrinkage, irregular shape, plasma membrane blebbing, cytoplasmic azurophilic lytic vesicles, apoptotic bodies, and fragmenting nuclei.

In conductance with the present in vivo investigation, in vitro assay revealed that $U$. lactuca polysaccharides have marked dose-dependent anticancer and cytotoxicity effects on breast carcinoma cell lines (MCF-7) as the concentration increases from 25 to $200 \mu \mathrm{g} / \mathrm{mL}$. These results are in agreement with prior study ${ }^{38}$ which reported that the crude polysaccharides of fruit bodies of Lentinus polychrous Lév 
had cytotoxic effects on MCF-7 and in accordance with other previous publication, ${ }^{39}$ which found that polysaccharides from Porphyra yezoensis inhibited the growth of a panel of human tumor cell lines, and such effects were dose-dependent. Recently, Ahmed and Ahmed ${ }^{11}$ found that U. lactuca polysaccharides have strong cytotoxicity effects against Ehrlich cells, hepatoma cell lines (HepG2), and colon carcinoma cell lines (HCT116).

Tumor suppressor protein $\mathrm{p} 53$ and anti-apoptotic protein bcl-2 are closely related to the majority of human cancers. ${ }^{40}$ Apoptotic marker p53 is a critical regulator of apoptosis in many cell types. It stimulates a wide network of signals that act through either extrinsic or intrinsic pathways of apoptosis ${ }^{41}$ by activating the transcription of downstream genes such as p21 and Bax to induce apoptotic process which inhibits the growth of cells with damaged DNA or cancer cells. On the other hand, bcl-2 has been reported to function primarily by blocking the apoptosis pathway. ${ }^{42} \mathrm{Bcl}-2$ gene product is a negative regulator of apoptosis, which forms a heterodimer complex with Bax and neutralizes the effect of pro-apoptosis. ${ }^{43} \mathrm{Bcl}-2$ has emerged as an important clinical prognostic marker in breast cancer. ${ }^{44,45}$

The present study tried to explain the antiproliferative effects of $U$. lactuca polysaccharides on p53 and bcl-2 by using immunohistochemical techniques. The photomicrographs of immunohistochemically stained breast tissue sections revealed that the administration of ulvan polysaccharides to normal rats produced a moderate increase in the amount of p53 and produced no change in the amount of bcl-2 as compared to breast tissue of normal control. On the other hand, the amount of expressed p53 was potentially decreased in DMBA-administered rats, whereas the amount of expressed bcl-2 was potentially increased as compared to normal control. These findings are supported by the findings of Sahin et $\mathrm{al}^{46}$ who reported that animals administered DMBA had an increased expression of bcl-2 in mammary tissues, and various subtypes of breast cancer have an elevated expression of bcl-2 among them. ${ }^{47}$ In addition, a recent study ${ }^{48}$ indicated that the DBMA-induced tumors are apparently the result of p53 inactivation as well as bcl-2 expression activation.

The treatment of DMBA-administered rats with ulvan polysaccharides increased the amount of p53 and decreased the amount of bcl-2 as compared to DMBA-administered control rats. This is in agreement with the study ${ }^{49}$ which reported that sulfated polysaccharide of algae increased the expression of p53 and decreased the expression of bcl-2 in lung cancer in mice. In addition, a previous experiment ${ }^{50}$ revealed that the expression of p53 increased slightly when HT-29 cell line (human colon cancer cells) was treated with Salicornia herbacea polysaccharides as compared with the control. The results are also in accordance with another study ${ }^{51}$ which indicated that polysaccharides isolated from Patrinia heterophylla upregulated the expression of p53 and Bax in tumor tissues of mice and significantly inhibited the expression of Bcl-2. Based on these results, it could be suggested that the anticancer activity of U. lactuca polysaccharides was considered to be derived from apoptosis induction, which might be associated with the increased expression of p53 and decreased expression of bcl-2 positive proteins.

In the present investigation, treatment with $U$. lactuca polysaccharides exhibited potential anticancer activity on DMBA-induced mammary carcinogenesis in rats. This study clearly demonstrated several observations. First, administration of DMBA was associated with the development of mammary carcinoma, elevated levels of serum NO and lipid peroxidation in breast tissue (markers of oxidative stress), elevated levels of serum TNF- $\alpha$, and decreased antioxidant enzymatic activities. Second, the administration of ulvan polysaccharides was associated with the decreased levels of serum NO, TNF- $\alpha$, and lipid peroxidation in breast tissue. In addition, it enhanced the antioxidant enzymatic activities in breast tissue, that is, possible therapeutic effects.

In mammary carcinogenesis, several molecules such as TNF- $\alpha$ mediate apoptosis. ${ }^{52}$ The present study revealed that the single-dose administration of DMBA produced a highly significant increase of serum TNF- $\alpha$ level as compared to the normal control group and that is in agreement with the findings of other studies. ${ }^{53,54}$ This high level may be due to increased production by the tumor-infiltrating lymphocytes and/or by the tumor cells. ${ }^{55,56} \mathrm{TNF}-\alpha$ seems to act as an endogenous tumor promoter when chronically produced, contributing to tissue remodeling and stromal development necessary for tumor growth and spread..$^{57}$ TNF- $\alpha$ is produced by mononuclear macrophage chiefly as well as by NK cells and T cells. TNF- $\alpha$ level refers to the degree of immunoreactions. ${ }^{58}$

The treatment of DMBA-administered rats with ulvan polysaccharides significantly decreased the elevated levels of serum TNF- $\alpha$ as compared to the DMBA-administered control. These results are in accordance with another study, ${ }^{58}$ which indicated that ginseng polysaccharide could lower the protein expression of TNF- $\alpha$ in the Peyer's patch lymphocyte in collagen-induced arthritis rats and the supernatant of lamina propria lymphocyte in normal rats for two reasons: first the activation of Th2 cells and the secretion of the 
inhibitors like interleukin (IL)-4, IL-10, and TGF- $\beta$ inhibited the organic immunologic response of foreign antigens. Second, because the $\mathrm{CD} 4^{+}$cell content in lamina propria is only $8.06 \%$, the relative concentration of antigen increased, which caused $\mathrm{CD}^{+} \mathrm{T}$-cell apoptosis. These findings are supported by previous finding ${ }^{59}$ which reported that Lentinus edodes polysaccharide administration significantly decreased the levels of serum, mucosal IL-2 and TNF- $\alpha$ in rats with oral ulceration. Similarly, there are reports about the constituents of the red alga Gracillaria verrucosa which indicate its antiinflammatory activity determined by its inhibitory effects on the production of the same pro-inflammatory mediators (NO, IL-6, and TNF- $\alpha$ ). ${ }^{60}$ In addition, these results are in agreement with results which reported that under the higher stimulation of both lipopolysaccharide and phorbol myristate acetate, the polysaccharides of Ganoderma tsugae (including FIII-2, FIII-2-a, FIII-2-b, and FIII-2-c) downregulate TNF- $\alpha$ production in human myelomonocytic leukemic cells. ${ }^{61}$ It was explained that cytokine gene expression might be regulated by these polysaccharides at transcriptional level. ${ }^{61}$

In the present study, DMBA-administered rats exhibited a profound elevation of serum NO level and breast lipid peroxidation as compared to normal control. These results are consistent with the results which found that serum and tissue lipid peroxidation and NO level were increased significantly in the breast cancer-bearing animals induced by DMBA. ${ }^{9}$ The present results are also in agreement with many previous reports. ${ }^{52,62-66}$ In consistency with the present study, the results of another study showed that an increase in the MDA level was observed in the lactiferous ducts of rats exposed to DMBA. ${ }^{67}$ The higher lipid peroxidation in breast tissue of DMBA-administered rats could be due to the formation of free radicals through an exhaustion of antioxidants leading to oxidative stress. ${ }^{65}$ Toxic property of DMBA is associated with its oxidative metabolism leading to the formation of reactive metabolites (epoxides and quinines), which are capable of generating free radicals. Metabolism of DMBA by the mixed function oxidases system often results in the formation of oxyradicals " $\mathrm{O}_{2}^{--}, \mathrm{H}_{2} \mathrm{O}_{2}$ and ${ }^{\circ} \mathrm{OH}$ " which bind covalently to nucleophilic sites on cellular macromolecules, thereby eliciting cancerous responses. ${ }^{9}$ The generation of ROS and the peroxidation of membrane lipids are well associated with the initiation of carcinogenesis. ${ }^{68}$

In the present study, the high significant increase in lipid peroxidation level after DMBA administration to rats is due to the significant acceleration in the oxidation of lipid. This acceleration in lipid peroxidation measured as thiobarbituric acid reactive substance content, which is attributed to the peroxidation of the membrane unsaturated fatty acids due to free radical propagation concomitant with the inhibition of bio-oxidase activities. ${ }^{69}$ Hence, oxidative stress induced due to the generation of free radicals in the target cells and tissues has been suggested to play an important role in carcinogenesis. ${ }^{70}$ It plays a role in the initiation and progression of breast cancer. ${ }^{71,72}$ Oxidative stress results from the excessive production of reactive oxygen species (ROS) that exhaust antioxidant defenses. These stress conditions cause DNA damage, resulting in the production of mutated tumor-suppressor genes. ${ }^{52}$ In addition, activated inflammatory cells produce ROS and NO, resulting in oxidative stress, which has been shown to be associated with tumor promotion. ${ }^{73-75}$ Moreover, ROS can be important mediators of damage to cell structures at high concentrations, including lipids and membranes, proteins, and nucleic acid. ${ }^{76} \mathrm{~A}$ critical role is played by macrophages in the innate and adaptive immunoresponses. Pathogens are engulfed by phagocytosis of macrophages and digested. ${ }^{77}$ This defense includes the secretion of inflammation mediators such as NO. ${ }^{78} \mathrm{NO}$ is a highly reactive free radical, which can form a number of oxidation products that induce initiation and promotion of cancer such as $\mathrm{NO}_{2}, \mathrm{NO}_{2} \cdot \mathrm{N}_{2} \mathrm{O}_{3}$, and $\mathrm{ONOO}^{-} .{ }^{78}$ In addition, overgeneration of $\mathrm{NO}$, a reactive nitrogen oxide species, during infection and chronic inflammation is thought to initiate cellular injury and carcinogenesis, for example, through nitrosative deamination of DNA bases and induction of lipid peroxidation. ${ }^{79,80}$ Endogenous nitric oxide (NO') plays a dual role in specialized tissues and cells, and acts as an essential physiological signaling molecule mediating various cell functions and also induces cytotoxic and mutagenic effects when present in excess. NO reacts rapidly with superoxide anion to form peroxynitrite, which may be cytotoxic by itself or easily decompose to the highly reactive and toxic hydroxyl radical and nitrogen dioxide. ${ }^{81}$

Lipid peroxidation is a chain reaction that involves the oxidation of polyunsaturated fatty acids in membranes induced by ROS and is an indicator of oxidative cell damage.$^{82}$ The major target of ROS in vivo or in vitro is membrane lipid peroxidation that leads to abnormalities in the structural integrity and function of the cell membrane. ${ }^{83} \mathrm{MDA}$, a secondary product of lipid peroxidation is used as an indicator of the rate of tissue chain reactions. ${ }^{84}$ It has been reported that products of lipid peroxidation may cause DNA damage. ${ }^{84,85}$ Lipid peroxidation is one of the major mechanisms of cellular injury which is caused by free radicals. ${ }^{86}$ Free radical-initiated oxidation of cellular membrane lipids can lead to cellular necrosis and is now accepted to be important in relation to 
various pathological conditions. ${ }^{87}$ Lipid peroxidation can be initiated by peroxynitrite (ONOO-) and peroxynitrous acid which are formed as a result of the reaction of superoxide with $\mathrm{NO}$ which are overproduced by oxidative stress. ${ }^{88}$ It has been suggested that excessively generated lipid peroxides at the primary site could be transferred through circulation to other organs and provoke damage by propagating lipid peroxidation. ${ }^{89}$

In the present study, the treatment of DMBA-administered rats with ulvan polysaccharides potentially decreased the elevated levels of serum $\mathrm{NO}$ and breast lipid peroxidation as compared to those of the DMBA-administered control rats. Our results are supported by the findings ${ }^{77}$ which reported that treatment with gum C-glycosylated derivative or its sulfated derivative resulted in a potent inhibition of the lipopolysaccharide-stimulated NO. Hence, they strongly inhibited the generation of nitric oxide in lipopolysaccharide-stimulated RAW murine macrophage. In addition, these results are in agreement with the results of Park et $\mathrm{a}^{90}$ who found that water-soluble polysaccharide from Eleutherococcus senticosus reduced the $\mathrm{NO}$ and lipid peroxidation levels in serum of mice. In the present study, polysaccharides extracted from the green alga, $U$. lactuca, profoundly decreased the serum NO level. These findings are supported by the findings of Gamal-Eldeen et a ${ }^{80}$ who found that polysaccharide extract from the brown alga, Sargassum latifolium, enhanced the macrophage proliferation; however, it dramatically inhibited the production of stimulated NO. Our findings are also in concurrence with the results of Cardoso et $\mathrm{al}^{91}$ which proved that fucoidan (a term used to define polysaccharides composed mainly of sulfated L-fucose and containing $<10 \%$ of other monosaccharides) from brown algae Fucus vesiculosus significantly reduced the NO concentration. The reduction of NO level in DMBA-administered group treated with ulvan polysaccharides may be due to the inhibition of NO synthase enzyme. ${ }^{72}$ The inhibitory property of NO may be due to a direct scavenging capacity to NO, an inhibition of the iNOS pathway, and/or a modulation of other factors in the NO cascade, for example, transcriptional factors. ${ }^{77}$

Human body is equipped with various antioxidants such as CAT, GPx, superoxide dismutase (SOD), GSH, ascorbic acid (vitamin C), and $\alpha$-tocopherol (vitamin E), which can counteract the deleterious action of ROS and protect from cellular and molecular damages. ${ }^{92}$

In the present study, the activities of antioxidant enzymes such as CAT, GST, GR, and GPx generation in the breast were examined. In addition, GSH content in breast tissue was determined.
Also, as compared to normal control, the single-dose administration of DMBA in rats produced a marked decrease in the activities of GST, GPx, CAT, and GR in the breast tissue. In addition, a substantial decrease in breast GSH content was detected. These results are in accordance with other studies ${ }^{66,93}$ which revealed that the total antioxidant level was detectably decreased in the serum of DMBA group as compared with the control group. Moreover, the present study is in agreement with Kaufmann et $\mathrm{al}^{33}$ who reported that the enzymic antioxidant SOD, CAT, and GPx levels in cancerinduced animals were reduced when compared to the control animals. The decrease in these enzymatic antioxidants may be attributed to the elucidation that oxidative stress due to exacerbated production of ROS may exhaust antioxidant defenses. Oxidative stress due to increased ROS levels coupled with the deficiency of host antioxidant defense mechanism might be a determining factor contributing in the development of cancer. ${ }^{94}$ Prasad et al ${ }^{14}$ revealed that a significant decrease of the enzyme SOD, CAT, GR, and GST in liver was recorded in the DMBA-administered rats. It was observed that there were decreases in antioxidant enzyme activities and GSH levels of heart and brain tissues of rats exposed to DMBA and concluded that DMBA treatment induces an increase in oxidative damage in rat tissues. ${ }^{95}$ This increase in oxidative production plays a role in DMBA-induced tissue damage which is in agreement with our results. The reduced activity of GST observed by DMBA administration may be partly due to the lack of its substrate (GSH) ${ }^{96}$ which occurs also due to reduced activity of GR. ${ }^{94}$

CAT is a peroxisomal heme protein that catalyzes the removal of hydrogen peroxide formed during the reaction catalyzed by SOD. Thus, SOD and CAT act as mutually supportive antioxidative enzymes, which provide protective defense against ROS. ${ }^{97}$ CAT activity was decreased in the DMBA-administered control group, which may be due to altered antioxidant status caused by carcinogenesis. Decrease of CAT activity was measured in patients with breast cancer and benign breast disease conditions..$^{98}$ The decrease in CAT activity in DMBA-administered control group may be due to the utilization of antioxidant enzymes in the removal of $\mathrm{H}_{2} \mathrm{O}_{2}$ released.

On the other hand, in the present study, the treatment of DMBA-administered rats with ulvan polysaccharides improved the decreased levels of breast GST, GPx, GR, and CAT activities and breast GSH contents. These results are in agreement with prior studies ${ }^{15,36,37}$ which discussed that Ulva spp. have good antioxidant activity in acetaminopheninduced hepatotoxicity in nicotinamide/streptozotocin- 
induced diabetes in albino rats. Our results are supported by Ruberto et al and Athukorala et al ${ }^{99,100}$ who suggested that antioxidant activity is one of the most important activities in marine bioactive substances and many algal and algaederived compounds exhibited potent antioxidant such as carotenoids, phenolics, terpenoids, and sulfated polysaccharides. The antioxidant activity of these compounds is mainly attributed to their scavenging activity against superoxide and hydroxyl radicals, chelating ability, quenching singlet and triplet oxygen, and reducing power.

Nonenzymatic and enzymatic antioxidants play a protective role against neoplastic transformation and ROS-mediated oxidative stress. ${ }^{83}$ It was reported that to protect cells from oxidative stress, radicals and nonradical reactive species including peroxides and superoxides need to be inactivated enzymatically by CAT, SOD, and GPx, antioxidant enzymes that provide the cellular defense against the intermediates of dioxygen reduction (superoxide radical, hydrogen peroxide, and hydroxyl radicals). ${ }^{94,101}$ The protection provided by ulvan polysaccharides is possible by scavenging of superoxide and peroxyl radicals. GST catalyzes the detoxification of electrophilic species including metabolites of DMBA to protect the cells against peroxidative damage. ${ }^{102}$ Increased antioxidant may be a result of a protective mechanism that develops against free radical damage, maintaining the normal biochemical process. ${ }^{66}$

It was reported that GST detoxifies carcinogens either by destroying their active reactive centers or by facilitating their excretion through a conjugation process. ${ }^{73} \mathrm{GR}$, an important enzyme required for reduced GSH maintenance, catalyzes reduced nicotinamide adenine dinucleotide phosphatedependent reduction of glutathione disulfide to GSH. ${ }^{103}$

Ulvan polysaccharides have antioxidant activity. Watersoluble polysaccharide from E. senticosus increased the activities of CAT and GPx in kidney ${ }^{90}$ and attenuated the renal dysfunction. ${ }^{104}$ The increase in antioxidant enzymes by $U$. lactuca polysaccharides suggests that it inhibits the process of oxidative stress-induced carcinogenesis. The protective effect of ulvan polysaccharides as indicated by reduced lipid peroxides could be due to an increase in GSH and the antioxidant enzymes GST, GPx, and CAT. ${ }^{105}$

The results of the present study revealed that $U$. lactuca polysaccharides have antioxidant activity. Hence, the damage induced by DMBA was prevented by the antioxidative properties of the ulvan polysaccharides, which was supported by a reported that states that the sulfated polysaccharides extracted from algae possess excellent antioxidant activities. ${ }^{106}$ Five polysaccharides have been extracted from five algae including one brown alga Laminaria japonica, one red alga Porphyra haitanensis, and three green algae Ulvapertusa, Enteromorphalinza, and Bryopsis plumose. These five polysaccharides had the strongest radical scavenging effect.

In conclusion, ulvan polysaccharides isolated from $U$. lactuca have potent antiproliferative and cytotoxic effect against breast carcinoma cell line in vitro and have potential chemopreventive effects against DMBA-induced breast adenoma and hyperplasia in vivo. These anticarcinogenic and ameliorative effects of polysaccharides may be mediated through the induction of apoptosis and enhancement of antioxidant defense system.

\section{Conclusion}

Ulvan polysaccharides might have potential chemopreventive effects against breast carcinogenesis during the initiation and promotion stages. These preventive effects may be mediated through the augmentation of apoptosis, suppression of oxidative stress and inflammation, and enhancement of antioxidant defense system.

\section{Acknowledgments}

The authors acknowledge Prof Dr Kawkab Abd El Aziz Ahmed, Professor of Pathology, Department of Pathology, Faculty of Veterinary Medicine, Cairo University, for her great help in reading histopathological sections of breast and in revising the histopathology part of the manuscript.

\section{Disclosure}

The authors report no conflicts of interest in this work.

\section{References}

1. Siegel R, Naishadham D, Jemal A Cancer statistics. CA Cancer J Clin. 2012;62:10-29.

2. Anderson BO, Yip CH, Ramsey SD, et al. Breast cancer in limitedresource countries: health care systems and public policy. Global Summit Health Care Systems and Public Policy Panel. Breast $J$. 2006;12(Suppl 1):S54-S69.

3. Chung SS, Vadgama JV. Curcumin and epigallocatechin gallate inhibit the cancer stem cell phenotype via down-regulation of STAT3-NFKB signaling. Anticancer Res. 2015;35:39-46.

4. Ahmed OM, Ashour MB, Mahmoud AM, Ahmed NA. Preventive effect of Spirulina versicolor and Enteromorpha flexuosa ethanolic extracts against diethylnitrosamine/benzo(A)pyrene-induced hapatocarcinogencity in rats. J Int Acad Res Multidiscipl. 2014;2(6):633-650.

5. Akhdar H, Legendre C, Aninat C, Morel F. Anticancer drug metabolism: chemotherapy resistance and new therapeutic approaches. In: Paxton J, editor. Topics on Drug Metabolism. Croatia: InTech Europe University Campus STeP Ri; 2012:137-170.

6. Gerhauser C, Alt A, Heiss E, et al. Cancer chemopreventive activity of xanthohumol, a natural product derived from hop. Mol Cancer Ther. 2002;1:959-969.

7. Ooi VE, Liu F. Immunomodulation and anti-cancer activity of polysaccharide-protein complexes. Curr Med Chem. 2000;7:715-729.

8. Zhang Q, Ning L, Xiguang L, Zengqin Z, Zhien L, Zuhong X. The structure of a sulfated galactan from Porphyra haitanensis and its in vivo antioxidant activity. Carbohydr Res. 2004;339:105-111. 
9. Moselhy S, Al Meslamani M. Chemopreventive effect of lycopene alone or with melatonin against the genesis of oxidative stress and mammary tumors induced by 7,12-dimethylbenz[a]anthracene in Sprague Dawley female rats. Mol Cell Biochem. 2008;319:175-180.

10. Gao J, Lauer FT, Dunaway S, Burchiel SW. Cytochrome P450 1B1 is required for 7,12-dimethylbenz[a]anthracene (DMBA) induced spleen cell immunotoxicity. Toxicol Sci. 2005;86:68-74.

11. Ahmed OM, Ahmed RR. Anti-proliferative and apoptotic efficacies of ulvan polysaccharides against different types of carcinoma cells. In vitro and in vivo. J Cancer Sci Ther. 2014;6:202-208.

12. Kaeffer B, Benard C, Lahaye M, Biottiere HM, Cherbut C. Biological properties of ulvan, a new source of green seaweed sulfated polysaccharides on cultured normal and cancerous colonic epithelial cells. Planta Med. 1999;65:527-531

13. Devaki T, Sathivel A, Balaji Raghavendran HR. Stabilization of mitochondrial and microsomal function by polysaccharide of Ulva lactuca on D-galactosamine induced hepatitis in rats. Chem Biol Interact. 2009; $177(2): 83-88$

14. Ahmed OM. Antihyperglycemic effects of water extract of Ulva lactuca and its polysaccharides in nicotinamide-streptozotocin-induced diabetic rats. Egypt J Zool. 2009;54:273-297.

15. Ahmed OM. Anti-hyperlipidemic, antioxidant and cardiac improving effects of water extract of Ulva lactuca and its polysaccharides in nicotinamide-streptozotocin-induced diabetic rats. Egypt J Zool 2010;54:253-272.

16. Gear R, Yan M, Schneider J, Succop P, Heffelfinger S, Clegg D. Charles River Sprague Dawley rats lack early age-dependent susceptibility to DMBA-induced mammary carcinogenesis. Int J Biol Sci. 2007;3:408-416.

17. Adams J, Heintz P, Gross N, et al. Acid/pepsin promotion of carcinogenesis in the hamster cheek pouch. Arch Otolaryngol Head Neck Surg. 2000;126(3):405-409.

18. Han B, Fukamachi K, Takasuka N, et al. Inhibitory effects of $17 \beta$-estradiol and 4- $n$-octylphenol on 7,12dimethylbenz[a] anthraceneinduced mammary tumor development in human c-Ha-ras protooncogene transgenic rats. Carcinogenesis. 2002;23(7):1209-1215.

19. Pandi M, Manikandan R, Muthumary J. Anticancer activity of fungal taxol derived from Botryodiplodia theobromae Pat., an endophytic fungus, against 7, 12 dimethyl benz(a)anthracene (DMBA)-induced mammary gland carcinogenesis in Sprague Dawley rats. Biomed Pharmacother. 2010;64(1):48-53.

20. Skehan P, Storeng R, Scudiero D, Monks A, McMahon J, Vistica D. New colorimetric cytotoxicity assay for anticancer-drug screening. J Natl Cancer. 1990;82(13):1107-1112.

21. Green LC, Wagner DA, Glogowski J, Sleipper PL, Tannenbaum SR. Analysis of nitrate, nitrite, and [15N] nitrate in biological fluids. Anal Biochem. 1982;126(1):131-138.

22. Preuss HG, Jarrel ST, Scheckenobach R, Lieberman S, Anderson RA. Comparative effect of chromium vanadium and Gymnema sylvestre on sugar-induced blood pressure elevations in SHR. J Am Coll Nutr. 1998;17(2):116-123.

23. Beutler E, Duron O, Kefly BM. Improved method for the determination of blood glutathione. J Lab Clin Med. 1963;61(5):882-888.

24. Mannervik B, Guthenberg C. Glutathione transferase (human placenta). Methods Enzymol. 1981;77:231-235.

25. Goldberg DM, Spooner RJ. In: Bergmeyen HV, editor. Methods of Enzymatic Analysis. 3rd ed. Deerfield Beach, FL: Verlog Chemie; 1983:258-265.

26. Aebi H. Catalase in vitro. Methods Enzymol. 1984;105:121-126.

27. Paglia DE, Valentine WN. Studies on the quantitative and qualitative characterization of erythrocyte glutathione peroxidase. J Lab Clin Med. 1967;70(1):158-169.

28. Rao M, Blane K, Zonnenberg M. PC-STAT statistical program. University of Georgia; 1985.

29. Samy R, Gopalakrishnakone P, Ignacimuthu S. Anti-tumor promoting potential of luteolin against 7,12-dimethylbenz( a)anthracene-induced mammary tumors in rats. Chem Biol Interact. 2006;164(1-2):1-14.
30. Lai H, Singh NP. Oral artemisinin prevents and delays the development of 7,12dimethylbenz[a]anthracene (DMBA) induced breast cancer in the rat. Cancer Lett. 2006;231(1):43-48.

31. Girolami F, Abbadessa G, Racca S, et al. Time-dependent acetylsalicylic acid effects on liver CYP1A and antioxidant enzymes in a rat model of 7,12 dimethylbenzanthracene (DMBA)-induced mammary carcinogenesis. Toxicol Lett. 2008;181(2):87-92.

32. Tikoo K, Kumar P, Gupta J. Rosiglitazone synergizes anticancer activity of cisplatin and reduces its nephrotoxicity in 7, 12-dimethyl benz a $\}$ anthracene (DMBA) induced breast cancer rats. BMC Cancer. 2009;9(1):107.

33. Kaufmann Y, Spring P, Klimberg VS. Oral glutamine prevents DMBAinduced mammary carcinogenesis via upregulation of glutathione production. Nutrition. 2008;24(5):462-469.

34. Dipple A, Nebzydoski JA. Evidence for the involvement of a diolepoxide in the binding of 7,12-dimethylbenz(a)anthracene to DNA in cells in culture. Chem Biol Interact. 1978;20(1):17-26.

35. Gao J, Mitchell LA, Lauer FT, Burchiel SW. p53 and ATM/ATR regulate 7,12-dimethylbenz[a]anthracene-induced immunosuppression. Mol Pharmacol. 2008;73(1):137-46.

36. Ahmed O, Fahim H, Ahmed R, Khedr M, Mekhaeel T, Abou Seif H. Protective effects of Ulva lactuca against acetaminophen-induced kidney injury. J Egypt Ger Soc Zool. 2008;56A:281-306.

37. Fahim H, Ahmed O, Ahmed R, Khedr M, Mekhaeel T, AbouSeif H Protective effects of Ulva lactuca against acetaminophen-induced liver injury. J Egypt Ger Soc Zool. 2008;56A:377-315.

38. Thetsrimuang C, Khammuang S, ChiablaemK, Srisomsap C, Sarnthima R. Antioxidant properties and cytotoxicity of crude polysaccharides from Lentinus polychrous Lév. Food Chem. 2011;128(3):634-639.

39. Zhang L, Cai C, Guo T, et al. Anti-cancer effects of polysaccharide and phycocyanin from Porphyra yezoensis. Marine Sci Technol. 2011;19(4):377-382.

40. Gu Q, Hu C, Chen Q, Xia Y, Feng J, Yang H. Development of a rat model by 3,4-benzopyrene intra-pulmonary injection and evaluation of the effect of green tea drinking on p53 and bcl-2 expression in lung carcinoma. Cancer Detect Prev. 2009;32(5-6): 444-451.

41. Yerlikaya A, Okur E, Ulukaya E. The p53-independent induction of apoptosis in breast cancer cells in response to proteasome inhibitor bortezomib. Tumour Biol. 2012;33:1385-1392.

42. Hussein AM, Ahmed OM. Regioselective one-pot synthesis and anti-proliferative and apoptotic effects of some novel tetrazolo[1,5-a] pyrimidine derivatives. Bioorg Med Chem. 2010;18(7):2639-2644.

43. Chaudhary SC, Siddiqui MS, Athar M, Alam MS. D-Limonene modulates inflammation, oxidative stress and Ras-ERK pathway to inhibit murine skin tumorigenesis. Hum Exp Toxicol. 2012;31:798-811.

44. Callagy GM, Pharoah PD, Pinder SE, et al. Bcl-2 is a prognostic marker in breast cancer independently of the Nottingham Prognostic Index. Clin Cancer Res. 2006;12(8):2468-2475.

45. Dawson SJ, Makretsov N, Blows FM, et al. BCL2 in breast cancer: a favourable prognostic marker across molecular subtypes and independent of adjuvant therapy received. Br J Cancer. 2010;103(5):668-675.

46. Sahin K, Tuzcu M, Sahin N, et al. Inhibitory effects of combination of lycopene and genistein on 7,12-dimethyl benz(a)anthracene-induced breast cancer in rats. Nutr Cancer. 2011;63(8):1279-1286.

47. Oakes SR, Vaillant F, Lim E, et al. Sensitization of BCL-2-expressing breast tumors to chemotherapy by the BH3 mimetic ABT-737. Proc Natl Acad Sci U S A. 2012;109(8):2766-2771.

48. Miliaras S, Anogeianaki A, Kefala V, et al. The role of P53 and Bcl-2 proteins in 7, 12-dimethylbenz-(a)-anthracene-induced tumor growth J Biol Regul Homeost Agents. 2011;25(3):359-364.

49. Zhai ZG, Jiang HD, Qin XM, Wang C. Therapeutic effect and mechanism of sulfate polysaccharide of algae on lung cancer. Zhonghua Jie He He Hu Xi Za Zhi. 2004;27(2):97-100.

50. Ryu DS, Kim SH, Lee DS. Anti-proliferative effect of polysaccharides from Salicornia herbacea on induction of G2/M arrest and apoptosis in human colon cancer cells. J Microbiol Biotechnol. 2009;19(11):1482-1489. 
51. Lu WZ, Geng GX, Li QW, Li J, Liu FZ, Han ZS. Antitumor activity of polysaccharides isolated from Patrinia heterophylla. Pharm Biol. 2010;48(9):1012-1017.

52. AbdEl-AzizM,HassanHA,MohamedMH,MekiAR,Abdel-GhaffarSK, Hussein MR. The biochemical and morphological alterations following administration of melatonin, retinoic acid and Nigella sativa in mammary carcinoma: an animal model. Int $J$ Exp Path. 2005; 86(6):383-396.

53. Ardizzoia A, Lissoni P, Brivio F, et al. Tumor necrosis factor in solid tumors: increased blood levels in the metastatic disease. J Biol Regul Homeost Agents. 1992;6(3):103-107.

54. Bower JE, Ganz PA, Aziz N, Fahey JL. Fatigue and proinflammatory cytokine activity in breast cancer survivors. Psychosom Med. 2002;64(4):604-611.

55. Lind DS, Tuttle TM, Bethke KP, Frank JL, McCrady CW, Bear HD. Expansion and tumour specific cytokine secretion of bryostatinactivated T-cells from cryopreserved axillary lymph nodes of breast cancer patients. Surg Oncol. 1993;2(5):273-282.

56. Kopreski MS, Lipton A, Harvey HA, Kumar R. Growth inhibition of breast cancer cell lines by combinations of anti-P185HER 2 monoclonal antibody and cytokines. Anticancer Res. 1996;16(1):433-436.

57. Balkwill F, Mantovani A. Inflammation and cancer: back to Virchow? Lancet. 2001;357(9255):539-545.

58. Zhao H, Zhang W, Xiao C, et al. Effect of ginseng polysaccharide on TNF- $\alpha$ and IFN- $\gamma$ produced by enteric mucosal lymphocytes in collagen induced arthritic rats. J Med Plants Res. 2011;5(9):1536-1542.

59. Yu Z, Hua Y, Qian Y, Yan L. Effect of Lentinus edodes polysaccharide on oxidative stress, immunity activity and oral ulceration of rats stimulated by phenol. Carbohydr Polym. 2009;75:115-118.

60. Dang HT, Lee HJ, Yoo ES, et al. Anti-inflammatory constituents of the red alga Gracilaria verrucosa and their synthetic analogues. $J$ Nat Prod. 2008;71(2):232-240.

61. Ai-dong L, Ke-yan Z, Qing-fang M, Takashi I, Jie Z, Xiao-fang F. Effect of polysaccharides from fruit body of Ganoderma tsugae on bidirectional regulation of proinflammatory cytokine production in THP-1 cells. Chem Res Chinese Univ. 2009;25(4):487-491.

62. Jadeski LC, Chakraborty C, Lala PK. Role of nitric oxide in tumour progression with special reference to a murine breast cancer model. Can J Physiol Pharmacol. 2002;80(2):125-135.

63. Jang TJ, Kim DK. Inducible nitric oxide synthase expression of tumor and stromal cells is associated with the progression of 7,12-dimethylbenz[a] anthracene-induced rat mammary tumors. Cancer Lett. 2002;182(2):121-126.

64. Kumaraguruparan R, Subapriya R, Viswanathan P, Nagini S. Tissue lipid peroxidation and antioxidant status in patients with adenocarcinoma of the breast. Clin Chem Act. 2002;325(1-2):165-170.

65. Perumal SS, Shanthi P, Sachdanandam P. Combined efficacy of tamoxifen and coenzyme Q10 on the status of lipid peroxidation and antioxidants in DMBA induced breast cancer. Mol Cell Biochem. 2005;273(1-):151-160.

66. Hamdy SM, Abdel-Latif K, Drees EA, Soliman SM. Prevention of rat breast cancer by genistin and selenium. Toxicol Ind Health. 2011;28(8):746-757.

67. Ozdemir I, SelamogluTalas Z, Gu, M, et al. Inhibition of DMBA induced rat mammary duct damage by novel synthetic organoselenium compounds. Exp Anim. 2006;55(5):449-455.

68. Davis L, Kuttan G. Effect of Withania somnifera on DMBA induced carcinogenesis. J Ethnopharmacol. 2001;75(2-3):165-168.

69. Zheng H, Zhuo L, Chen R, Chen X. Effect of ionizing radiation biooxidase activities in cytoplasm of mouse blood and liver cells. Chin $J$ Rad Med Prot. 1996;16(3):179-185.

70. Huang YL, Sheu JY, Lin TH. Association between oxidative stress and changes of trace elements in patients with breast cancer. Clin Biochem. 1999;32(2):31-36.

71. Mobley JA, Brueggemeier RW. Estrogen receptormediated regulation of oxidative stress and DNA damage in breast cancer. Carcinogen. 2004;25(1):3-9.
72. Hussein MR, Abu-Dief EE, Abd El-Reheem MH, Abd-Elrahman A. Ultrastructural evaluation of the radioprotective effects of melatonin against X-ray-induced skin damage in Albino rats. Int $J$ Exp Pathol. 2005;86(1):45-55.

73. Weitzman SA, Gordon LI. Inflammation and cancer: role of phagocytegenerated oxidants in carcinogenesis. Blood. 1990;76(4):655-663.

74. Yoshimura A. Signal transduction of inflammatory cytokines and tumor development. Cancer Sci. 2006;97(6):439-447.

75. Franco R, Schoneveld O, Georgakilas AG, Panayiotidis MI. Oxidative stress, DNA methylation and carcinogenesis. Cancer Lett. 2008;266(1):6-11.

76. Poli G, Leonarduzzi G, Biasi E, Chiarpotto F. Oxidative stress and cell signaling. Curr Med Chem. 2004;11(9):1163-1182.

77. Gamal-Eldeen AM, Amer H, Helmy WA. Cancer chemopreventive and anti-inflammatory activities of chemically modified guar gum. Chem Biol Interact, 2006;161(3):229-240.

78. MacMicking J, Xie QW, Nathan C. Nitric oxide and macrophage function. Annu Rev Immunol. 1997;15:323-350.

79. Puntoni M, Marra D, Zanardi S, Decensi A. Inflammation and cancer prevention. Ann Oncol. 2008;19(Suppl 7):225-229.

80. Gamal-Eldeen AM, Ahmed EF, Abo-Zeid MA. In vitro cancer chemopreventive properties of polysaccharide extract from the brown alga, Sargassum latifolium. Food Chem Toxicol. 2009;47(6):1378-1384.

81. Ohshima H, Bartsch H. Chronic infections and inflammatory processes as cancer risk factors: possible role of nitric oxide in carcinogenesis. Mutat Res. 1994;305(2):253-264.

82. Okawa H, Ohishi N, Yagi K. Assay for lipid peroxides in animal tissues by thiobarbituric acid reaction. Anal Biochem. 1979;95(2):351-358.

83. Kolanjiappan K, Manoharan S, Kayalvizhi M. Measurement of erythrocytes lipids, lipid peroxidation, antioxidants and osmotic fragility in cervical cancer patients. Clin Chem Acta. 2002;326(1-2): $143-149$.

84. Wang M, Dhingra K, Hittelman WN, Liehr JG, de Andrade M, Li D. Lipid peroxidation-induced putative malondialdehyde-DNA adducts in human breast cancer tissue. Cancer Epi Biom Prev. 1996;5(9): 705-710.

85. Caporaso N. The molecular epidemiology of oxidative damage to DNA and cancer. J Natl Cancer Inst. 2003;95(17):1263-1265.

86. Esterbauer H, Chesseman KH. Determination of aldehydic lipid peroxidation products: malonaldehyde and 4-hydroxy-nonenal. Meth Enzymol. 1990;186:407-421.

87. Balaji Raghavendra Rao H, Sathivel A, Devaki T. Antihepatotoxic nature of Ulva reticulata (Chlorophyceae) on acetaminopheninduced hepatotoxicity in experimental rats. J Med Food. 2004;7(4): 495-497.

88. Millar TM. Peroxynitrite formation from the simultaneous reduction of nitrite and oxygen by xanthene oxidase. FEBS Lett. 2004; 562(1-3):129-133.

89. Gutteridge JM. Lipid peroxidation and antioxidants as biomarkers of tissue damage. Clin Chem. 1995;41(12 Pt 2):1819-1828.

90. Park EJ, Nan JX, Zhao YZ, et al. Water-soluble polysaccharide from Eleutherococcus senticosus stems attenuates fulminant hepatic failure induced by D-galactosamine and lipopolysaccharide in mice. Basic Clin Pharmacol Toxicol. 2004;94(6):298-304.

91. Cardoso ML, Xavier CA, Bezerra MB, et al. Assessment of zymosaninduced leukocyte influx in a rat model using sulfated polysaccharides. Planta Med. 2010;76(2):113-119.

92. Jagetia GC, Rao SK. Evaluation of the antineoplastic activity of guduchi (Tinospora cordifolia) in Ehrlich ascites carcinoma bearing mice. Biol Pharm Bull. 2006;29(3):460-466.

93. Manoharan S, Balakrishnan S, Menon VP, Alias LM, Reena AR. Chemopreventive efficacy of curcumin and piperine during 7,12-dimethylbenz[a]anthracene-induced hamster buccal pouch carcinogenesis. Singapore Med J. 2009;50(2):139-146.

94. Prasad S, Kalra N, Shukla Y. Hepatoprotective effects of lupeol and mango pulp extract of carcinogen induced alteration in Swiss albino mice. Mol Nut Food Res. 2007;51(3):352-359. 
95. Talas ZS, Ozdemir I, Yilmaz I, Gok Y, Orun I. The investigation of the antioxidative properties of the novel synthetic organoselenium compounds in some rat tissues. Exp Biol Med. 2008;233(5):575-579.

96. Bhuvaneswari V, Abraham SK, Nagini S. Combinatorial antigenotoxic and anticarcinogenic effects of tomato and garlic through modulation of xenobiotic-metabolizing enzymes during hamster buccal pouch carcinogenesis. Nutrition. 2005;21(6):726-731.

97. Weydert CJ, Waugh TA, Ritchie JM, et al. Overexpression of manganese or copper-zinc superoxide dismutase inhibits breast cancer growth. Free Radic Biol Med. 2006;41(2):226-237.

98. Gonenc A, Erten D, Aslan S, Akyncy M, Simşek B, Torun M. Lipid peroxidation and antioxidant status in blood and tissue of malignant breast tumour and benign breast disease. Cell Biol Int. 2006;30(4): 376-380.

99. Ruberto G, Baratta MT, Biondi DM, Amico V. Antioxidant activity of extracts of the marine algal genus Cystoseira in a micellar model system. Appl Phycol. 2001;13:403-407.

100. Athukorala Y, Nam K, Jeon Y. Antiproliferative and antioxidant properties of an enzymatic hydrolysate from brown alga Ecklonia cava. Food Chem Toxicol. 2006;44(7):1065-1074.
101. Manoharan S, Kavitha K, Senthil N, Renju GL. Evaluation of anticarcinogenic effects of Clerodendron inerme on 7,12-dimethylbenz(a) anthracene-induced hamster buccal pouch carcinogenesis. Singapore Med J. 2006;47(12):1038-1043.

102. Ishikawa T, Esterbauer H, Sies H. Role of cardiac glutathione transferase and of the glutathione $\mathrm{S}$-conjugate export system in biotransformation of 4-hydroxynonenal in the heart. $J$ Biol Chem 1986;261(4):1576-1581.

103. Wilkinson J, Clapper ML. Detoxification enzymes and chemoprevention. Proc Soc Exp Biol Med. 1997;216(2):192-200.

104. Yokozawa T, Rhyu DY, Chen CP. Protective effects of Acanthopanax Radix extract against endotoxemia induced by lipopolysaccharide. Phytother Res. 2003;17(4):353-357.

105. Monga J, Chauhan CS, Sharma M. Human epithelial carcinoma cytotoxicity and inhibition of DMBA/TPA induced squamous cell carcinoma in Balb/c mice by Acacia catechu heartwood. J Pharm Pharmacol. 2011;63(11):1470-1482.

106. Zhang Z, Wang F, Wanga X, Liu X, Hou Y, Zhang Q. Extraction of the polysaccharides from five algae and their potential antioxidant activity in vitro. Carbohydr Polym. 2010;82:118-121.
Breast Cancer - Targets and Therapy

\section{Publish your work in this journal}

Breast Cancer - Targets and Therapy is an international, peerreviewed open access journal focusing on breast cancer research, identification of therapeutic targets and the optimal use of preventative and integrated treatment interventions to achieve improved outcomes, enhanced survival and quality of life for the cancer patient

\section{Dovepress}

The manuscript management system is completely online and includes a very quick and fair peer-review system, which is all easy to use. Visit http://www.dovepress.com/testimonials.php to read real quotes from published authors. 